\title{
Management Earnings Forecasts and Book-Tax Differences
}

\author{
Anastasia Kraft ${ }^{1}$ \\ ${ }^{1}$ Carl von Ossietzky University Oldenburg, Germany \\ Correspondence: Anastasia Kraft, Carl von Ossietzky University Oldenburg, Ammerländer Heerstr. 114-118, \\ 26129 Oldenburg, Germany. E-mail: anastasia.kraft@uni-oldenburg.de
}

Received: November 24, 2014

Accepted: December 30, 2014

Online Published: February 25, 2015

doi:10.5539/ijef.v7n3p1

URL: http://dx.doi.org/10.5539/ijef.v7n3p1

\begin{abstract}
This study is the first to investigate the incremental usefulness of book-tax differences (BTDs) to discretionary accruals in detecting earnings management to meet quarterly management earnings forecasts. Upward managed earnings that do not affect taxable income result in larger BTDs. This paper uses the ranked tax-to-book income ratio and decomposes BTDs in normal and discretionary BTDs, and tax avoidance activity. The findings show that higher discretionary accruals, larger BTDs, and more aggressive tax avoiding activity are associated with higher probability of meeting management earnings forecasts. The results imply that BTDs are incrementally useful to discretionary accruals in detecting earnings management. Moreover, the analysis shows that firms are more likely to meet management earnings forecasts during the financial crisis of 2008.
\end{abstract}

Keywords: meeting management earnings forecasts, book-tax differences, BTDs, tax-to-book income ratio, discretionary book-tax differences, tax avoidance, earnings management, discretionary accruals, financial crisis

\section{Introduction}

This study is the first that investigates the incremental usefulness of book-tax differences (BTDs) beyond discretionary accruals in detecting earnings management to meet/beat (Note 1) voluntary earnings forecasts (i.e., management earnings forecasts). Although prior research reports that earnings response coefficients and meeting earnings targets such as avoiding loss, earnings decline or analysts' forecasts are associated with tax accounts (e.g., Phillips, Pincus, \& Rego, 2003; Weber, 2009), the relationship between meeting management earnings forecasts and BTDs is unexplored, yet. The ongoing research on discretion of managers (see Habib \& Hansen, 2008, for literature review) and the fact that capital markets react to meeting or missing the earnings targets emphasizes the importance of detecting earnings management. This paper combines the area of earnings management, voluntary earnings disclosures and BTDs by showing that BTDs are incrementally useful to discretionary accruals in detecting earnings management to meet/beat management earnings forecasts. Analyzing the period during the financial crisis (2008-2010), the results show that firms are more likely to meet management earnings forecasts.

This study develops a measure for discretionary book-tax differences, uses tax avoidance based on the methodology of Desai and Dharmapala (2006) and applies the ranked tax-to-book income ratio developed by Lev and Nissim (2004). This paper differs from Desai and Dharmapala (2006) by decomposing BTDs in normal BTDs, discretionary BTDs that comprise the degree of earnings management, and a component that results from aggressive tax avoidance strategies. Since total accruals are decomposed in normal and discretionary accruals, I suggest that BTDs, which are not attributable to normal accruals reflect earnings management and tax sheltering practices. Following Desai and Dharmapala (2006) and Hoi, Wu, and Zhang (2013), the component of BTDs that is not determined by total accruals reflects firm's aggressive tax avoidance activity.

Due to greater discretion under General Accepted Accounting Principles (GAAP) in comparison to tax law, discretionary effects of income-increasing accruals do not affect taxable income (Lev \& Nissim, 2004; Hanlon, 2005). This results in higher book income relative to tax income (larger BTDs). Following prior research (e.g., Manzon \& Plesko, 2002; Badertscher et al., 2009), I suggest that managers prefer to increase earnings to meet their earnings forecasts without affecting taxable income (non-conforming earnings management). I suppose that greater upward earnings management should be reflected in larger discretionary accruals and larger BTDs, and hypothesize that both proxies are appropriate to detect earnings management. I expect that firms with larger discretionary accruals and BTDs are more likely to meet management earnings forecasts. Following the 
argumentation of Phillips, Pincus, and Rego (2003), a significant relationship between the proxies for earnings management and meeting earnings benchmarks indicates incremental usefulness of the former for detecting earnings management.

In contrast to Phillips, Pincus, and Rego (2003), who analyze-among others-analysts' forecasts, I find that larger discretionary accruals are associated with higher probability of meeting the earnings benchmark. These results support the findings of Kraft, Lee, and Lopatta (2014), who investigate the relationship between meeting management earnings forecasts and earnings management before insider trades. My results indicate that including both discretionary accruals and BTDs, the model tends to be more accurate. The model's ability to discriminate between firms that meet vs. miss the earnings benchmark is slightly higher when BTDs are included. Overall, the findings imply that book-tax differences are incrementally useful to discretionary accruals in detecting earnings management to meet quarterly management earnings forecasts. However, the results tend to be sensitive to the extent of management earnings forecast errors supporting the findings of Kraft, Lee, and Lopatta (2014). When I restrict the sample to management earnings forecasts errors to be maximum 5 cents, BTDs are not associated with meeting management earnings forecasts. Restricting the sample to larger forecasts errors (i.e., maximum of 10 or 15 cents), supports the results for the whole sample by showing that larger book-tax differences are incrementally useful in detecting earnings management. Moreover, the regressions show comparable results for ranked tax-to-book income ratio, discretionary BTDs, and tax avoidance. Their predicted probability of meeting management earnings forecasts does not statistically differ implicating that no one measure tends to be more accurate. Furthermore, I analyze the impact of the financial crisis of 2008 on the probability of meeting management earnings forecasts by using two subsamples (2008-2010 and 1995-2007). The results show that firms are more likely to meet management earnings forecasts during the financial crisis. I find larger forecast errors and discretionary BTDs as well as tax avoidance for the period 2008-2010. This implies that managers disclose more pessimistic forecast errors and engage more in activities that result in larger BTDs during the financial crisis of 2008.

I extend to the literature on management earnings forecasts, information content of taxes and earnings management by relating most closely to Phillips, Pincus, and Rego (2003). This study goes beyond the paper of Phillips, Pincus, and Rego (2003) to analyze whether the BTDs are associated with the probability of meeting quarterly management earnings forecasts. I use a larger sample that comprises $16,224(1,713)$ observations (firms) covering the period 1995-2010. While Phillips, Pincus, and Rego (2003) analyze the deferred tax expense, the proxies for BTDs used in this study comprise temporary, permanent differences and tax accruals. The results are robust for different ranking of the tax-to-book income ratio. Furthermore, this paper develops a measure for discretionary BTDs, which reflects earnings management and tax sheltering practices and analyzes the relationship between tax avoidance and meeting management earnings forecasts. I also analyze the impact of the financial crisis of 2008 on the probability of meeting the earnings benchmarks.

The findings of this study should be of interest to several parties such as regulatory authorities, companies, and researchers who deal with issues of information of taxes, voluntary disclosure, earnings management, and consequences of financial crises. The findings show that BTDs are an appropriate metric to detect earnings management and therefore, should be considered in future research. Since investors react to meeting or beating earnings benchmarks, they should be aware of potential earnings management when firms meet management earnings forecasts.

The remainder of this study is organized as follows. The next section provides a literature review and develops the hypotheses. Section 3 describes the research design and the sample. Section 4 presents results of the analyses. Section 5 concludes.

\section{Literature Review and Hypothesis Development}

\subsection{Related Literature}

Extensive research deals with earnings management and voluntary disclosures including management earnings forecasts (see Healy \& Palepu, 2001; Habib \& Hansen, 2008; Hirst, Koonce, \& Venkataraman, 2008, for literature review). Anilowski, Feng, and Skinner (2007) and Das, Kim, and Patro (2011) show that management earnings forecasts provide meaningful information for investors. However, the disclosure of management earnings forecasts is voluntary and can be influenced by managers' incentives. Previous research investigates the incentives of voluntary disclosures such as the reduction in information asymmetry (e.g., Coller \& Yohn, 1997; Verrecchia, 2001), reduction in litigation costs (Skinner, 1994; Bartov, Givoly, \& Hayn, 2002), and equity compensation incentives (e.g., Noe, 1999; Aboody \& Kasznik, 2000). Prior studies focus on accrual-based earnings management to avoid negative earnings surprises (e.g., Brown, 1998; Degeorge, Patel, \& Zeckhauser, 
1999; Matsumoto, 2002; Burgstahler \& Eames, 2006).

In their literature review, Hanlon and Heitzman (2010) and Graham, Raedy, and Shackelford (2012) summarize the research on income taxes in different settings. Previous studies analyze whether income tax accounts provide meaningful information about earnings quality such as growth or persistence of future returns and earnings (e.g., Lev \& Nissim, 2004; Hanlon, 2005; Schmidt, 2006; Ayers, Jiang, \& Laplante, 2009; Blaylock, Shevlin, \& Wilson, 2012). The results imply that large BTDs provide incremental useful information and signal low earnings quality.

Other studies investigate tax accounts such as tax contingency account or tax cushion (e.g., Cazier et al., 2011; Gupta, Laux, \& Lynch, 2011), the valuation allowance of deferred tax assets (e.g., Visvanathan, 1998; Frank \& Rego, 2006), deferred tax accounts (e.g., Phillips, Pincus, \& Rego, 2003; Gordon \& Joos, 2004; Hanlon, 2005), tax-to-book income ratio (e.g. Mills \& Newberry, 2001; Lev \& Nissim, 2004; Weber, 2009), and tax expense (e.g., Dhaliwal, Gleason, \& Mills, 2004; Cook, Huston, \& Omer, 2008; Comprix, Mills, \& Schmidt, 2012) as instruments of earnings management. Phillips, Pincus, and Rego (2003) report that the deferred tax expense is incrementally useful to total accruals in detecting earnings management to avoid earnings decline or loss. However, they find no evidence that the deferred tax expense is associated with the probability of meeting analysts' forecasts. In contrast to total accruals, they find no significant relationship between the discretionary accruals and meeting the analysts' forecasts or avoiding earnings decreases.

Prior studies report that firms engage in tax avoidance strategies that results in decreasing effective tax rates (e.g., Rego, 2003; Desai \& Dharmapala, 2006; Desai \& Dharmapala, 2009). Dhaliwal, Gleason, and Mills (2004) and Cook, Huston, and Omer (2008) report that firms reduce ETR from the third to the fourth quarter when they would have missed the analysts' forecasts. Analyzing factors that affect book-tax gaps, Mills and Newberry (2001) use confidential tax return data to calculate total differences between book and taxable income. They report that earnings management incentives are associated with larger BTDs and note that firms with earnings increases appear to have larger book-tax differences. Hoi, Wu, and Zhang (2013) find that firms with excessive irresponsible CSR activities have a higher probability of engaging in tax sheltering, greater discretionary / permanent book-tax differences and a lower cash effective tax rate. Overall, prior research reports that firms manage tax accounts to meet earnings targets and that earnings management is associated with the gap between book and tax income (e.g., Desai, 2003; Phillips, Pincus, \& Rego, 2003; Desai \& Dharmapala, 2006).

\subsection{Hypothesis Development}

The literature reviews of Healy and Wahlen (1999) and Fields, Lys, and Vincent (2001) show that market incentives appear to dominate other incentives, such as a reduction in information asymmetry (e.g., Ajinkya \& Gift, 1984; Hassell \& Jennings, 1986; Diamond \& Verrecchia, 1991; Kim \& Verrecchia, 1994; Verrecchia, 2001) or a reduction in litigation costs (e.g., Lev, 1992; Francis, Philbrick, \& Schipper, 1994; Skinner, 1994, Skinner, 1997). However, management earnings forecasts is a voluntary disclosure and managers have some discretion about the amount of forecast that may results in optimistic or pessimistic earnings targets. This study does not primary focus on managers' incentives to meet management earnings forecasts. The paper aims rather to analyze whether BTDs-beyond discretionary accruals-are incrementally useful in detecting earnings management. Earnings management is described as managers' discretion over accounting numbers (Watts \& Zimmermann, 1990). Using discretionary accruals as a metric to detect earnings management, prior research reports a positive association with earnings benchmarks (management earnings forecasts: e.g., Kasznik, 1999; Kraft, Lee, \& Lopatta, 2014; avoid earnings decline or loss, and analyst' forecasts: e.g., Degeorge, Patel, \& Zeckhauser, 1999; Ayers, Jiang, \& Yeung, 2006). To confirm the findings of previous studies, I analyze the impact of earnings-increasing accruals on the probability of meeting management earnings forecasts. Following the argumentation of Phillips, Pincus, and Rego (2003), I suggest that if discretionary accruals increase the probability of meeting management earnings forecasts, they are incrementally useful in detecting earnings management. This leads to my first hypothesis.

H1: Discretionary accruals are useful in detecting earnings management to meet/beat management earnings forecasts.

Guidelines to prepare financial statements (GAAP) that do not completely correspond to the rules of tax law result in temporary and permanent differences between book and taxable income. Temporary differences (e.g., depreciation) result from accruals for revenue and expense that affect taxable income and book income in different periods (Phillips, Pincus, \& Rego, 2003; Hanlon, 2005). Permanent differences (e.g., recognition of goodwill, R\&D process) arise when revenue or expense is recognized under one system but not under the other (Manzon \& Plesko, 2002; Lev \& Nissim, 2004). Previous research argues that there is more discretion under 
GAAP than under tax law (e.g., Plesko, 2003; Phillips, Pincus, \& Rego 2003; Badertscher et al., 2009).

Prior studies analyze the ability of BTDs to predict future returns (e.g., Lev \& Nissim, 2004; Weber, 2009). They argue that the relation between BTDs and future returns stems from mispricing. Weber (2009) argues that it may be too costly to process tax-related information and Lev and Nissim (2004) suggest that market participants fail to fully appreciate the information of taxes. Since BTDs can arise from unbiased application of accounting and tax rules as well as from earnings management, it is not fully possible to distinguish between the two reasons and therefore, leads to mispricing. I assume that mispricing or incomplete appreciation of tax related information is at least partly attributable to opportunistic earnings management that result in larger BTDs. If executives manage earnings upward to meet their earnings forecasts, they can manipulate earnings generating permanent and/or temporary book-tax differences (non-conforming earnings management). Non-conforming earnings managements affects book income without increasing taxable income, such as deferring expenses for financial reporting or increasing revenues (e.g., expending the useful life of depreciable assets, reducing the provision for bad debts, aggressively recognizing unearned revenue). For instance, Badertscher et al. (2009), Weber (2009) and Seidman (2010) suggest that the book-tax gap is a reasonable proxy for detecting earnings management. Prior studies show that the BTDs are incrementally useful in detecting earnings management to meet earnings benchmarks such as avoiding earnings decline or loss, or analysts' forecasts (e.g., Burgstahler, Elliott, \& Hanlon, 2002; Phillips, Pincus, \& Rego, 2003; Schrand \& Wong, 2003). Yet, the relationship between book-tax differences and the likelihood of meeting management earnings forecasts is unexplored. This paper aims to close this gap.

Lev and Nissim (2004) construct an after-tax measure for BTDs that comprises temporary and permanent differences, and discretionary tax accruals (e.g., changes in tax valuation allowance). They use the tax-to-book income ratio as a proxy for earnings management and argue that their measure should be a more powerful proxy to detect earnings management than specific tax accounts. This study applies the methodology of Lev and Nissim (2004) to calculate the tax-to-book income ratio and decomposes BTDs to estimate the components that are attributable to earnings management and tax avoidance based on the methodology of Desai and Dharmapala (2006).

Income-increasing accruals leave the taxable income unaffected because the tax income excludes discretionary effects such as provision for bad debt or changes in depreciation (Lev \& Nissim, 2004; Hanlon, 2005). If managers use non-conforming earnings management, they increase book income (denominator) without affecting taxable income (numerator). This results in lower tax-to-book income ratio reflecting larger BTDs and greater earnings management. However, the tax-book income ratio will not reflect conforming management. This means that if managers use earnings management that has the same impact on book and taxable income, the tax-to-book income ratio will be unaffected. Following the suggestion of Manzon and Plesko (2002) and Badertscher et al. (2009), I assume that executives prefer to manage earnings upward to meet their management earnings forecasts without increasing taxable income. Hence, I expect that firms with larger book-tax differences are more likely to meet management earnings forecasts. Following the argumentation of Phillips, Pincus, and Rego (2003), I claim that if larger BTDs are associated with higher probability of meeting management earnings forecasts, they are incrementally useful in detecting earnings management. The second hypothesis is as follows.

$\mathrm{H} 2$ : Book-tax differences are incrementally useful in detecting earnings management to meet/beat management earnings forecasts.

BTDs can also arise besides tax planning or earnings management due to normal differences between the regulations for tax purposes and financial reporting (Blaylock, Shevlin, \& Wilson, 2012) or by aggressive tax reporting in order to reduce the taxable income (Hanlon, 2005). Furthermore, executives can engage in earnings management that affect both tax and book income simultaneously (conforming earnings management). Therefore, the proxy to detect earnings management, tax-to-book income ratio, may be subject of estimation error.

\section{Empirical Methodology}

\subsection{Research Design}

\subsubsection{Meeting Management Earnings Forecasts}

This study uses meeting or beating management earnings forecast as a proxy for detecting earnings management. Meet indicates whether the firm meets the management earnings forecasts $($ Meet $=1)$ or not $($ Meet $=0)$. Management earnings forecast errors (MngError) are calculated by the difference between the current earnings measure and the forecast value. I use the most recent management earnings forecasts because they better capture market expectations and represent the benchmark for managers. In the robustness checks, the sample is restricted 
by the extent of management earnings forecast errors. Meet5, Meet10, or Meet15 are used as a binary dependent variable for firms that miss or beat the forecast by maximum of 5 cents, 10 cents, and 15 cents, respectively.

\subsubsection{Accruals}

I use the model of Dechow, Richardson, and Tuna (2003) to estimate discretionary accruals. In contrast to Dechow, Sloan, and Sweeney (1995), they assume that not all credit sales are discretionary. The expected change in credit sales/receivables controls for their non-discretionary part and is captured by $k$. While the modified Jones' model (1990) classifies the change in receivables ( $\Delta$ Receiv) as discretionary, the model of Dechow, Richardson, and Tuna (2003) classifies the expected change in receivables based on changes in sales ( $\triangle$ Sales) as non-discretionary. I estimate $k$ as the coefficient from the regression of $\Delta$ Receiv on $\Delta$ Sales for each two-digit SIC code and quarter $\left(\Delta\right.$ Receiv $_{q}=\alpha+k \Delta$ Sales $\left._{q}+\varepsilon\right) . k$ is restricted to lie between 0 and 1 . Dechow, Richardson, and Tuna (2003) include the lagged scaled total accruals $\left(\right.$ TotAcc $_{i, q-1} /$ Assets $\left._{i, q-2}\right)$ to capture the predictable portion of total accruals and they adjust for future sales $\left(\Delta\right.$ Sales $\left._{q+1}\right)$. The authors argue that if a firm is growing and therefore, increases its inventory to account for expected future sales, this expected increase in inventory does not represent the discretionary part.

For quarterly data, previous studies include indicator variables for fiscal quarters to calculate accruals (e.g., Barton \& Simko, 2002; Gong, Louis, \& Sun, 2008; Greco, 2012). Managers' incentives and discretion for earnings management may vary across quarters (Jeter \& Shivakumar, 1999). Altamuro, Beatty, and Weber (2005) and Kerstein and Rai (2007) show greater earnings management in the fourth quarter (see Dechow, Ge, \& Schrand, 2010, for literature review). I modify the model of Dechow, Richardson, and Tuna (2003) by including a binary variable $4 F q t r$ to capture the effects of the fourth quarter because they use annual data (Note 2). The estimated error terms from the cross-sectional regression for each two-digit SIC code and quarter represents the discretionary accruals (DiscAcc).

$$
\begin{aligned}
\frac{\text { TotAcc }_{i q}}{\text { Assets }_{i, q-1}}=\beta_{0}+\beta_{1} \frac{1}{\text { Assets }_{i, q-1}}+ & \beta_{2} \frac{(1+k) \Delta \text { Sales }_{i q}-\Delta \text { Receiv }_{i q}}{\text { Assets }_{i, q-1}}+\beta_{3} \frac{\text { PPE }_{i q}}{\text { Assets }_{i, q-1}}+\beta_{4} \frac{\text { TotAcc }_{i, q-1}}{\text { Assets }_{i, q-2}} \\
& +\beta_{5} \frac{\Delta \text { Sales }_{i, q+1}}{\text { Sales }_{i q}}+\beta_{6} 4 F q \text { Fr }_{q}+\varepsilon_{i q} .
\end{aligned}
$$

where $i$ stands for the firm and $q$ for the quarter. To avoid possible problems resulting from non-operating events such as reclassification or acquisitions in estimating accruals using a balance sheet approach, accruals are calculated using the data from the statements of cash flows (Hribar \& Collins, 2002). TotAcc is total accruals calculated by income before extraordinary items minus operating cash flows (Compustat item "IBCQ" [Compustat item "OANCFY" - Compustat item "XIDOCY"]), $\triangle$ Receiv is change in accounts receivable (Compustat item "RECTQ" in $q$ - Compustat item "RECTQ" in $q-1$ ), PPE (Note 3) is gross property, plant, and equipment (Compustat item "PPEGTQ"), and $\triangle$ Sales $_{\mathrm{q}+1}$ is change in revenues (Compustat item "SALEQ" in $q+$ 1 - Compustat item "SALEQ" in $q$ ). The variables are scaled (i.e., normalized) by total assets (Compustat item "ATQ"). $4 F q t r$ is an indicator variable, which equals 1 for the fourth fiscal quarter, and 0 otherwise.

\subsubsection{Book-Tax Differences}

I use the methodology developed by Manzon and Plesko (2002) and Lev and Nissim (2004) to calculate BTDs. Because tax return data is not publicly available, Lev and Nissim (2004) construct an after tax ratio of tax-to-book income $(T A X)$, using accounting data. Investigating tax information as a proxy for earnings quality, prior studies focus on specific tax accounts, e.g., deferred taxes or valuation allowance. Lev and Nissim (2004) argue that the advantage of $T A X$ is that it reflects temporary (e.g., depreciation) and permanent differences (e.g., goodwill impairment), and tax accruals (valuation allowance). Prior literature points out that calculating taxable income using accounting data can be subject of estimation error (see Hanlon, 2005; Desai \& Dharmapala, 2006, for more details). For instance, the tax rate for foreign operations may differ from the U.S. statutory rate that used to estimate taxable income. Furthermore, net operating losses (NOLs) can result in a tax refund or tax expense of zero. Therefore, the use of financial data offers little information about taxable income of NOL-firms (Hanlon, 2003).

The taxable income is estimated as current tax expense divided by the U.S. statutory tax rate $(\tau)$ (see Lev \& Nissim, 2004, for a detailed discussion). I calculate the quarterly current tax expense as a difference between total income taxes (Compustat item "TXTQ") less deferred income taxes (Compustat item "TXDIQ"). If deferred taxes are not reported, they are replaced by zero. The statutory tax rate is $35 \%$ for the period analyzed (1995-2010). The after tax ratio of tax-to-book income (TAX) is calculated as taxable income multiplied by $(1-\tau)$ divided by income before extraordinary items (Compustat item "IBQ"). 
Prior studies show that book-tax differences vary across industries and years (e.g., Plesko, 1999; Desai, 2003). Following previous research, I rank $T A X$ to control for these issues. Moreover, ranking the proxies mitigates potential estimation errors of taxable income and overweighting of outlying observations (Hanlon, 2005; Weber, 2009).

While Lev and Nissim (2004) use industry based quintile ranks, Weber (2009) uses, among others, decile ranks by calendar year. To robust my results, I use different procedures for ranking of TAX. $r_{-} T A X y$ is the decile ranking of $T A X$ for each fiscal year scaled to range from [0,1]. $r_{-} T A X y i$ is the decile ranking of TAX for each fiscal year and industry (two-digit SIC code) scaled to range from [0,1]. $R_{-} T A X i$ is an ordered categorical variable within industries (two-digit SIC code) with values between 1 (lowest quintile of TAX) and 5 (highest quintile of TAX). R_TAXYi is an ordered categorical variable within fiscal year and industry (two-digit SIC code) with values between 1 and 5. Firms with higher book income relative to tax income have lower tax-to-book income ratio $(T A X)$, and therefore included in lower ranks of $T A X$.

In section 4.3, I develop the proxy for the discretionary part of BTDs (DiscBTD) and calculate a proxy for tax avoidance activity (TaxAvoid) using the methodology of Desai and Dharmapala (2006) to analyze whether they have an incremental information content for detecting earnings management.

\subsubsection{Regression Method}

Following Kraft, Lee, and Lopatta (2014), I use a logistic regression to analyze the association between meeting management earnings forecasts and BTDs. The logistic regression presents odds ratios, which quantify the likelihood of meeting management earnings forecast. Firstly, I analyze whether managers use accrual-based earnings management to meet their earnings forecasts.

Model 1:

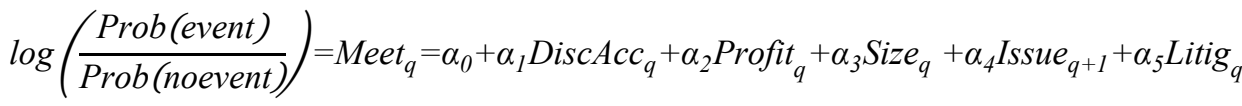

$$
\begin{aligned}
& +\alpha_{6} \mathrm{CFOVOl}_{q}+\alpha_{7} \text { Range }_{q}+\alpha_{8} \text { Horizon }_{q}+\sum_{m=1}^{M} \alpha_{9 m} \text { Industry }_{q}+\sum_{y=1}^{Y} \alpha_{10} \text { year }_{y}+\varepsilon_{q}
\end{aligned}
$$

where $\left(\frac{\operatorname{Prob}(\text { event })}{\operatorname{Prob}(\text { noevent })}\right)$ is the ratio of probability of meeting management earnings forecasts to the probability of missing the forecast, Meet is indicator variable which equals 1 if the firm meets or beats the management earnings forecast, and 0 otherwise. Firm subscripts are suppressed. Year indicates the fiscal year (Note 4). I use several control variables, which are described below.

Secondly, the study investigates whether larger BTDs - beyond higher discretionary accruals - increase the probability of meeting management earnings forecasts and thus, indicate usefulness to discretionary accruals in detecting earnings management. Therefore, I include discretionary accruals and the proxy for BTDs in one regression.

Model 2:

$$
\begin{aligned}
& \log \left(\frac{\operatorname{Prob}(\text { event })}{\operatorname{Prob}(\text { noevent })}\right)=\text { Meet }_{q}=\alpha_{0}+\alpha_{1} \text { DiscAcc }_{q}+\alpha_{2} \text { Rank }_{\text {TAX }}+\alpha_{3} \text { Profit }_{q}+\alpha_{4} \text { Size }_{q}+\alpha_{5} \text { Issue }_{q+1} \\
& +\alpha_{6} \text { Litig }_{q}+\alpha_{7} \text { CFOVOl }_{q}+\alpha_{8} \text { Range }_{q}+\alpha_{9} \text { Horizon }_{q}+\sum_{m=1}^{M} \alpha_{11 m} \text { Industry }_{q}+\sum_{y=1}^{Y} \alpha_{12} \text { year }_{y}+\varepsilon_{q}
\end{aligned}
$$

where Rank_TAX is a proxy for the ranked tax-to-book income ratio (TAX) calculated as $r_{-} T A X y, r_{-} T A X y i$, $R \_T A X i$, or $\bar{R} \_T A X y i$.

I expect a positive relationship between meeting earnings forecasts (Meet) and discretionary accruals (DiscAcc). This implies that discretionary accruals are useful in detecting earnings management and that firms are more likely to meet the management earnings forecasts when they use income-increasing accruals (H1). As described in section 2.2, I propose that upward earnings management to meet management earnings forecasts results in larger BTDs. Using the tax-to-book income ratio $(T A X)$, greater earnings management leads to lower $T A X$ that are included in lower quintiles $\left(R_{-} T A X i\right.$, or $\left.R_{-} T A X y i\right)$ or deciles $\left(r_{-} T A X y, r_{-} T A X y i\right)$. Therefore, I expect that Rank_TAX is negatively associated with the probability of meeting management earnings forecasts.

Exponentiated coefficients $\left(e^{\beta}\right)$ from a logistic regression represent the odds ratio $(\alpha)$. The odds are defined as the ratio of the probability of success (meeting management earnings forecasts, Meet $=1$ ) to the probability of failure (missing the earnings forecasts, Meet $=0$ ). The percentage change in odds for a unit change in the explanatory variable is calculated by the difference of the odds ratio minus one and then multiplied by 100 . If the 
change in odds is positive (negative), a unit change in the independent variables increases (decreases) the probability of meeting management earnings forecasts.

\subsubsection{Control Variables}

Following previous research, I include control variables that could have an impact on earnings and/or earnings forecasts. For instance, Burgstahler and Dichev (1997) and Dechow, Richardson, and Tuna (2003) report that executives manage earnings to avoid losses (Degeorge, Patel, \& Zeckhauser, 1999). Therefore, I include an indicator variable (Profit) which equals 1 if firm's actual earnings (EPS) equal at least zero, and 0 otherwise. I expect a positive relation between Meet and Profit. Previous studies on equity issuance show that firms increase the frequency of earnings forecasts (e.g., Ruland \& Tung, 1990) and use earnings management to meet the earnings benchmark around the time of an equity issuance (e.g., Cohen \& Zarowin, 2010). I control for common shares issuances (Issue) in the following quarter scaled by the market value at the beginning of the quarter (Compustat item "CSHIQ") / Compustat item "PRCCQ" x Compustat item "CSHOQ"). Prior studies report that managers' forecasting behavior is associated with firm's size (e.g., Baginski, Hassell, \& Kimbrough, 2002). Therefore, I include the proxy Size, which is calculated by the logarithm of total assets at the end of the quarter (Compustat item "ATQ"). Gong, Li, and Xie (2009) report lower forecasts errors for larger firms and Baginski and Hassell (1997) conclude that larger firms benefit less from precise earnings forecasts. I propose that larger firms have more possibilities to manage earnings towards the earnings forecasts and have a higher reputation risk. Therefore, I expect that larger firms are more likely to meet management earnings forecasts. Baginski, Hassell, and Kimbrough (2002) show that litigation costs affect managerial incentives to manage earnings or to bias forecasts. I include the dummy variable (Litig) that equals 1 if the firm belongs to one of the four industries that are most at risk of litigation (biotechnology, computer, electronics, and retail) (Francis, Philbrick, \& Schipper, 1994), and 0 otherwise, expecting a positive relationship. Following Gong, Li, and Xie (2009) and Kraft, Lee, and Lopatta (2014), I use cash flow volatility (CFOVol) to control for business development. CFOVol is the standard deviation of operating cash flows (as described above) scaled by the lagged total assets up to the last 20 quarters. $\mathrm{Xu}$ (2010) shows that managers overestimate the accruals persistency in range forecasts by reporting a negative relationship between current accruals and the following earnings forecasts. A dummy variable (Range) is included, which is equal to 1 if a firm discloses a range forecast and 0 otherwise, to control for forecast precision. I do not predict a relationship between Meet and the control variable Range because this paper does not focus on the accuracy of forecasts. Ajinkya, Bhojraj, and Sengupta, 2005 report that managers' forecasts with shorter horizon are less pessimistic. However, Zang (2012) proposes that during the period, firm can use real actions and accrual-based earnings management to meet the earnings target. I control for the forecast horizon using the variable (Horizon), calculated by the logarithm difference of days between the forecast date and the period end.

\subsection{Sample Development}

Management forecasts of quarterly earnings are collected from the First Call's Company Issued Guidance (CIG) database for the period 1995-2010 (Note 5). Forecasts prior to 1995 are excluded due to little coverage in the CIG database. Chuk, Matsumoto, and Miller (2013) discuss the characteristics of the database. They report that firms, which release an EPS forecast and at least one specific dollar amount are more likely to be represented on CIG. Therefore, I keep only point and closed-range forecasts in the sample and exclude open-range and qualitative estimates and only investigate EPS forecasts. For closed-range estimates, I use the average forecast. Chuk, Matsumoto, and Miller (2013) note that the coverage of CIG is more complete for forecasts after 1997. To address this issue, I exclude management earnings forecasts prior to 1997, or to 1998 in untabulated analyses (available on request). The results are similar to the findings of this paper and the inferences are unchanged (Note 6). I include management earnings forecasts for quarter $q+1$ issued at or after the actual earnings reporting date for quarter $q$ and before the earnings announcement for quarter $q+1$. If several forecasts are provided, I use the last earnings forecast. Actual earnings are obtained from the First Call Historical Database (FCHD). This results in 31,440 observations. Following prior studies, regulated firms such as utilities (SIC codes 4400-5000 from Compustat) and financial institutions (SIC codes 6000-6999) are excluded because they are likely to have different earnings management incentives in comparison to non-regulated firms, or they do not have to account for income taxes, such as mutual funds or trusts. Observations with missing financial data from Compustat are dropped and management earnings forecast errors are truncated at the 1st and 99th percentiles. Following prior literature, observations with negative current tax expense are excluded (Hanlon, 2005; Weber, 2009). For the calculation of quarterly discretionary accruals, at least six two-digit SIC-quarter observations are required (Note 7). The final sample comprises 16,224 (1,713) observations (firms). 


\section{Results}

\subsection{Descriptive Statistics for the Earnings Management Examination}

Table 1 provides the definitions of the variables used in the analyses and table 2 presents the descriptive statistics. Both the mean and the median of discretionary accruals are 0.000 . The mean discretionary accruals of firms that meet or beat their management earnings forecasts are positive $(0.001)$, while the discretionary accruals for firms that miss their earnings targets are negative (-0.001). The mean comparison test for the subgroups shows that they are statistically different. Using decile ranking of TAX $\left(r_{-} T A X y\right)$, the $t$-test reveals no significant difference between the two groups. In contrast, $r_{-} T A X y i$ and quintile ranked $T A X\left(R_{-} T A X i\right.$ and $\left.R_{-} T A X y i\right)$ are statistically different in the two subgroups. The mean Size of firms that meet the earnings benchmark is higher and statistically different from firms, which miss the management earnings forecasts. Untabulated results reveal 9,410 (5,608) observations for Profit equals 1 when firms meet (miss) management earnings forecasts. There are $8,030(4,575)$ range forecasts when managers meet (miss) the earnings benchmarks. This implies that profitable firms and companies with a range forecast more frequently meet the management earnings forecasts as discussed in section 3.1. The mean comparison test shows that Profit and Litig are statistically different in the subgroups.

Table 1. Definition of variables

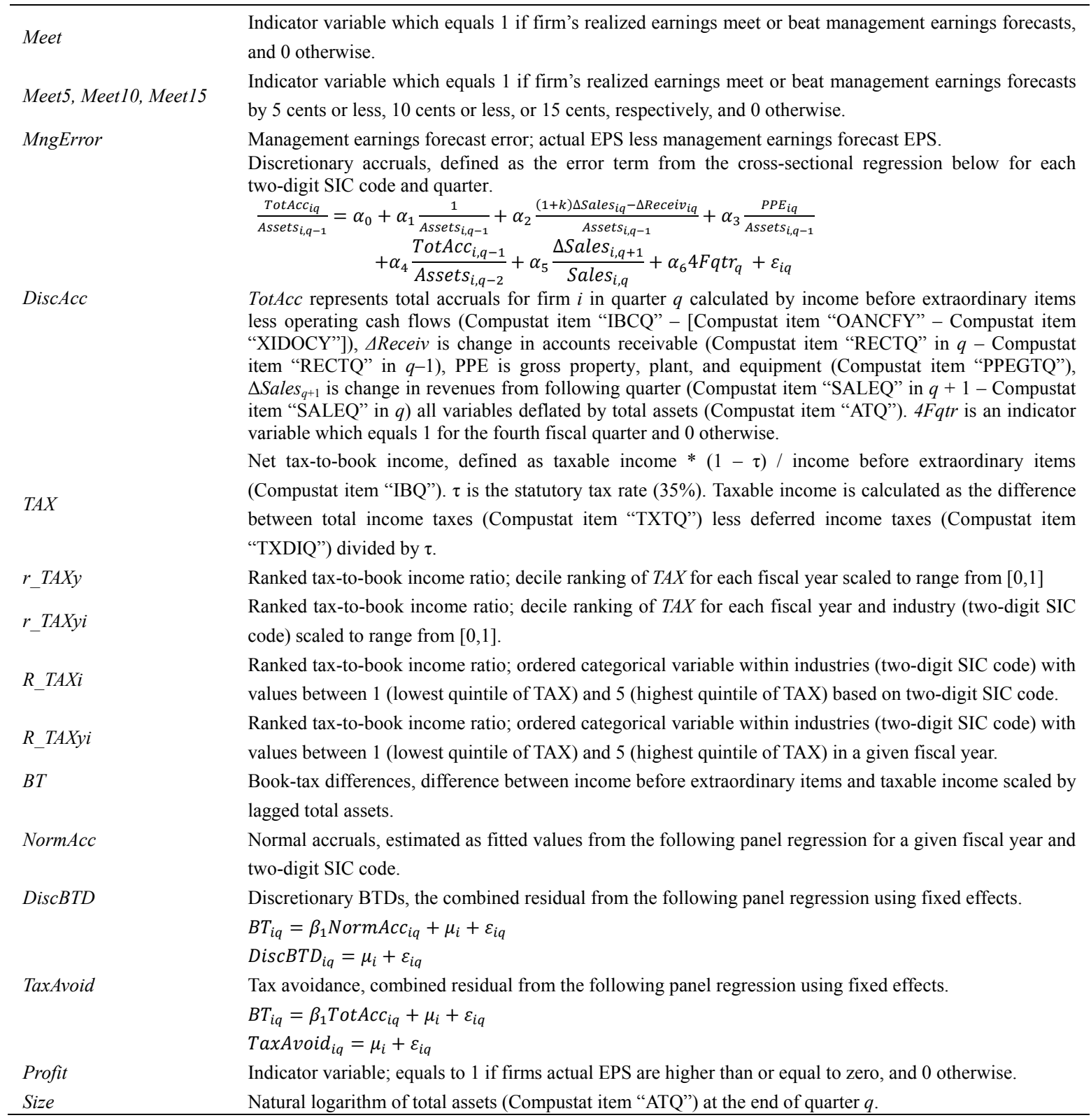




\begin{tabular}{ll}
\hline Issue & Common shares issuances (Compustat item "CSHIQ") in the following quarter scaled by market value of \\
& equity (Compustat item "PRCCQ" x Compustat item "CSHOQ")at the beginning of the. \\
Iitig & Indicator variable, equals to 1 if the firm belongs to one of the four industries that are most at risk of \\
& litigation (biotechnology, computer, electronics, and retail), and 0 otherwise. \\
& Cash flow volatility; calculated by the standard deviation of operating cash flows (Compustat item \\
"OANCFY" - Compustat item "XIDOCY"),) divided by the lagged total assets (Compustat item "ATQ") & for maximum the last 20 quarters. \\
Range $_{t}$ & Forecast specificity; equal to 1 if a firm discloses a range forecast, and 0 otherwise. \\
Horizon $_{\text {IncomeXTR }}$ & Forecast horizon; logarithm difference of days between the forecast's date and period-end for \\
& management earnings forecasts. \\
\hline
\end{tabular}

Note. Table 1 describes the variables used in the paper.

Table 2. Descriptive statistics

\begin{tabular}{|c|c|c|c|c|c|c|c|c|c|c|c|}
\hline & \multirow[b]{2}{*}{ Mean } & \multirow[b]{2}{*}{ Std Dev } & \multirow[b]{2}{*}{ Median } & \multirow[b]{2}{*}{ Min } & \multirow[b]{2}{*}{ Max } & \multirow[b]{2}{*}{$\mathrm{n}$} & \multicolumn{2}{|c|}{ Meet $=1(n=9,951)$} & \multicolumn{2}{|c|}{ Meet $=0(n=6,273)$} & \\
\hline & & & & & & & Mean & Median & Mean & Median & \\
\hline DiscAcc & 0.000 & 0.028 & 0.000 & -0.291 & 0.212 & 16,224 & 0.001 & 0.000 & -0.001 & 0.000 & $* * *$ \\
\hline MngError & -0.032 & 0.157 & 0.010 & -1.100 & 0.470 & 16,224 & 0.041 & 0.025 & -0.147 & -0.070 & $* * *$ \\
\hline r_TAXy & 0.5 & 0.3 & 0.5 & 0.1 & 1.0 & 16224 & 0.5 & 0.5 & 0.6 & 0.6 & $*$ \\
\hline r_TAXyi & 0.5 & 0.3 & 0.5 & 0.1 & 1.0 & 16224 & 0.5 & 0.5 & 0.5 & 0.6 & \\
\hline R_TAXi & 3.0 & 1.4 & 3.0 & 1.0 & 5.0 & 16,224 & 3.0 & 3.0 & 3.1 & 3.0 & $* * *$ \\
\hline R_TAXyi & 3.0 & 1.4 & 3.0 & 1.0 & 5.0 & 16224 & 3.0 & 3.0 & 3.1 & 3.0 & $*$ \\
\hline Size & 6.7 & 1.6 & 6.6 & 3.3 & 10.8 & 16,224 & 6.8 & 6.6 & 6.6 & 6.6 & $* * *$ \\
\hline CFOVol & 0.066 & 0.039 & 0.055 & 0.018 & 0.246 & 16,224 & 0.066 & 0.055 & 0.067 & 0.055 & $*$ \\
\hline Issue & 0.1 & 0.1 & 0.0 & 0.0 & 0.6 & 16,224 & 0.1 & 0.0 & 0.1 & 0.0 & \\
\hline Horizon & 3.5 & 1.0 & 4.0 & 0.0 & 6.2 & 16,224 & 3.5 & 4.0 & 3.4 & 3.9 & $* * *$ \\
\hline
\end{tabular}

Note. Panel A of Table 2 provides the number of observations of subgroups meeting/beating vs. missing management earnings forecasts. The variables are as defined in Table 1. Variables are winsorized at the 1st and 99th percentiles. I compare the differences between the two subgroups using a $t$-test on mean. $* * *, * *$, and $*$ indicate the the two-tailed $p$-value $<0.01, p<0.05$, and $p<0.1$, respectively.

\subsection{Spearman Correlations}

Table 3 contains Spearman's rank correlations. I find a positive and significant correlation (Spearman's rho = 0.0299 , sig $=0.000)$ between discretionary accruals $($ DiscAcc $)$ and the proxy for meeting management earnings forecasts (Meet). As expected, Spearman's rho (-0.0306) reflects a negative and significant correlation $(\mathrm{sig}=$ 0.000 ) between Meet and $R_{-} T A X i$. This confirms the assumption that lower TAX (higher book income relative to tax income) is associated with meeting management earnings forecasts. However, using other ranks of $T A X$, there is no significant relation between Meet and $r_{-} T A X Y, r_{-} T A X y i$, or $r_{-}$TAXYi. Moreover, proxies for ranked $T A X$ are negatively associated with management earnings forecast errors (MngError) indicating that firms with higher book income relative to tax income (lower ranks of TAX) are associated with positive MngError (actual less forecast). However, I find a positive relation between DiscAcc and the proxies for BTDs. The results show positive and significant Spearman's rho between Meet and Profit, Size, Issue, Horizon, Range, and Litig supporting the discussions described in section 3.1. However, CFOVol shows a negative Spearman's rho. The correlations between the variables used in regressions are modest suggesting there are no concerns regarding multicollinearity (Note 8). 
Table 3. Spearman's rank correlations

\begin{tabular}{|c|c|c|c|c|c|c|c|c|c|c|c|c|c|c|}
\hline & Meet & DiscAcc & MngError & r_TAXy & r_TAXyi & R_TAXy & R_TAXyi & Profit & Size & Issue & CFOVol & Horizon & Range & Litig \\
\hline Meet & 1 & & & & & & & & & & & & & \\
\hline DiscAcc & $0.0299 *$ & 1 & & & & & & & & & & & & \\
\hline MngError & $0.8435 *$ & $0.0278^{*}$ & 1 & & & & & & & & & & & \\
\hline r_TAXy & -0.012 & $0.0319^{*}$ & $-0.0258^{*}$ & 1 & & & & & & & & & & \\
\hline r_TAXyi & -0.0048 & $0.0438^{*}$ & $-0.0147^{*}$ & $0.8769^{*}$ & 1 & & & & & & & & & \\
\hline R_TAXi & $-0.0306^{*}$ & $0.0409^{*}$ & $-0.0474^{*}$ & $0.8660 *$ & $0.9432 *$ & 1 & & & & & & & & \\
\hline R_TAXyi & -0.0105 & $0.0389 *$ & $-0.0216^{*}$ & $0.8649 *$ & $0.9750 *$ & $0.9365^{*}$ & 1 & & & & & & & \\
\hline Profit & $0.0959 *$ & $0.0785^{*}$ & $0.0820^{*}$ & $0.3837 *$ & $0.3536^{*}$ & $0.3441^{*}$ & $0.3274 *$ & 1 & & & & & & \\
\hline Size & $0.0338^{*}$ & -0.0052 & $0.0508^{*}$ & $0.0838^{*}$ & $0.0546^{*}$ & $0.0268^{*}$ & $0.0432 *$ & $0.2732 *$ & 1 & & & & & \\
\hline Issue & $0.0717^{*}$ & -0.008 & $0.0559^{*}$ & $-0.1402 *$ & $-0.1203^{*}$ & $-0.1179 *$ & $-0.1158^{*}$ & $-0.2892 *$ & $-0.4772 *$ & 1 & & & & \\
\hline CFOVol & $-0.0140 *$ & $-0.0428 *$ & $-0.0257^{*}$ & $-0.0356^{*}$ & $-0.0712 *$ & $-0.0513 *$ & $-0.0615 *$ & $-0.1302 *$ & $-0.2995^{*}$ & $0.0873 *$ & 1 & & & \\
\hline Horizon & $0.0506^{*}$ & 0.0109 & $0.1030^{*}$ & $-0.0631^{*}$ & -0.0039 & $-0.0343 *$ & $-0.0158^{*}$ & $0.0517^{*}$ & $0.0806^{*}$ & $-0.0579 *$ & $-0.0829 *$ & 1 & & \\
\hline Range & $0.0908^{*}$ & -0.0082 & $0.1097^{*}$ & $0.0367^{*}$ & $0.0513^{*}$ & $0.0137^{*}$ & $0.0423 *$ & $0.0418^{*}$ & 0.0052 & $0.0391^{*}$ & $-0.0870^{*}$ & $0.1202^{*}$ & 1 & \\
\hline
\end{tabular}

Note. Panel A of Table 3 presents the Spearman correlations for the exclusive sample. The variables are as defined in Table 1. All continuous variables are winsorized at the 1st and 99th percentiles. * indicates significant Spearman coefficients at two-sided $p$-value $\leq 0.10$.

\subsection{Regression Results}

Using the regression models described in section 3.1, I analyze whether book-tax differences are incrementally useful to discretionary accruals in detecting earnings management to meet management earnings forecasts. Table 4 reports the logistic regression results for the different proxies of BTDs $\left(r_{-} T A X y, r_{-} T A X y i, R_{-} T A X i\right.$, and $\left.R_{-} T A X y i\right)$ (Note 9).

If the odds ratio is greater (lower) than one, the variable has a positive (negative) effect on the probability of meeting management earnings forecast. I report the Chi-square statistics for the joint significance of explanatory variables by testing whether the parameters are zero. The test is performed separately for the variables of interest and control variables, year, and industry dummies. To analyze whether BTDs provide incremental information in detecting earnings management, I compare the model including only discretionary accruals (model 1) and the model including both discretionary accruals and proxies for BTDs (model 2). In non-linear regression, there is no measure of fit that is comparable with $R^{2}$ for linear regressions (see Hosmer and Lemeshow, 2004; Green, 2012, for details). I compare the models using the area under the Receiver Operating Characteristic (ROC) curve and the Bayesian information criterion (BIC). The ROC curve plots detecting the true signal (sensitivity) against the false signal (specificity). The area under the ROC curve gives model's ability to discriminate between meeting or missing earnings benchmark. In literature, BIC is used to compare logistic models (Cameron \& Trivedi, 2010; Green, 2012). The model with lower BIC is preferred.

The results show that higher discretionary accruals (income-increasing accruals) increase the probability of meeting management earnings forecasts. This implies that discretionary accruals are useful in detecting earnings management, supporting hypothesis one (H1). The positive and statistically significant change in the odds ratio (odds ratio - 1) ranges from 9.646 using $r_{-}$TAXyi as a proxy for BTDs to 9.275 using model 1, both significant at $1 \%$ level. The change in odds ratio for the proxies of BTDs is negative, varying from -0.057 ( $\left.R \_T A X y i\right)$ to -0.290 $\left(r_{-} T A X y\right)$ and significant at $1 \%$ level. These findings imply that firms with larger book income relative to tax income (lower ranks of $T A X$ ) are more likely to meet the earnings benchmarks. In accordance with hypothesis 2 (H2), each of the ranked $T A X$ is incrementally useful in detecting earnings management to meet management earnings forecasts.

Consistent with my expectations, companies with positive EPS (Profit) and larger firms (Size) appear to be more likely to meet the earnings forecasts showing positive and significant change in odds ratio. Furthermore, firms that plan to issue new shares in the subsequent quarter (Issue), companies with higher litigation risk (Litig) and a range forecasts (Range) appear to be more likely to meet their earnings targets. Issue, Litig, and Range show a positive and significant effect on the probability of meeting management earnings forecasts. The positive change in odds for cash flow volatility $(\mathrm{CFOVO})$ implies that firms also manage cash flows (real earnings management, such as an increase in sales or a reduction in discretionary expenses) to meet the earnings benchmarks. However, longer forecast periods (Horizon) have a negative impact on the probability of meeting management earnings forecasts showing negative change in odds. 
The area under the ROC curve is a measure of discrimination assessing model's ability to classify the observations correctly in firms that meet/beat $($ Meet $=1)$ or miss $($ Meet $=0)$ the management earnings forecasts. If BTDs are incrementally useful to discretionary accruals in detecting earnings management, the measure of discrimination should increase. Using model 1, the area under the ROC curve is 0.687 . Including the proxies for BTDs, the measure slightly increases. Under model 2, the area under the ROC varies between 0.689 and 0.688. The area under the ROC curve is nearly 70\%, which indicates an appropriate discrimination (Hosmer \& Lemeshow, 2004). Moreover, BIC is lower for model 2 indicating that the model including both discretionary accruals and BTDs is considered to be better. Overall, the results indicate that book-tax differences are incrementally useful to discretionary accruals in detecting earnings management supporting the hypothesis two $(\mathrm{H} 2)$.

\subsubsection{Sensitivity Analysis}

Analyzing the relationship between meeting management earnings forecasts using accrual-based earnings management and insider trading, Kraft, Lee, and Lopatta (2014) report that their results are sensitive to the extent of management earnings forecast errors. I follow their methodology and use subsamples to analyze the information content of discretionary accruals and BTDs for earnings management when firms miss or beat management earnings forecasts by maximum of 5, 10, or 15 cents (Meet5, Meet10, or Meet15, respectively). Since the different proxies for ranked TAX show comparable results, Table 5 presents the results using $r_{-}$TAXyi. The findings are comparable when I use $r_{-} T A X y, R_{-} T A X i$, or $R_{-} T A X y i$.

Using Meet10 and Meet15 as dependent variables, the results support the findings above that DiscAcc and BTDs tend to be useful in detecting earnings management to meet management earnings forecasts. Using model 2 , the change in odds for DiscAcc ( $r_{-}$TAXYi) is 3.340 and 5.479 , respectively $(-0.181$ and -0.238 , respectively). However, I find no significant change in odds for DiscAcc and $r_{-}$TAXyi using Meet5. Untabulated results show that ranked TAX by year ( $r_{-} T A X Y$ and $\left.R_{-} T A X y\right)$ show a negative (-0.137 and -0.031 , respectively) and significant $(\mathrm{sig}=0.096$ and $\mathrm{sig}=0.086$, respectively) change in odds ratio. Overall, the results imply that book-tax differences are incrementally useful to discretionary accruals in detecting earnings management to meet the earnings benchmarks. However, the findings show that earnings management tends to be sensitive to the extent of management earnings forecasts supporting the results of Kraft, Lee, and Lopatta (2014). The area under the ROC curve including both discretionary accruals and BTDs is slightly larger than for discretionary accruals only. Comparing the information criterion, BIC for model 2 is smaller only using Meet 15. Overall, these results imply that the information content of discretionary accruals and BTDs is greater for larger MngError.

Table 4. Logistic regression, meeting management earnings forecasts and BTDs

\begin{tabular}{|c|c|c|c|c|c|}
\hline Dependent variable & Meet & Meet & Meet & Meet & Meet \\
\hline Independent variables & $\begin{array}{l}\text { Odds ratio } \\
p \text {-value }\end{array}$ & $\begin{array}{l}\text { Odds ratio } \\
p \text {-value }\end{array}$ & $\begin{array}{l}\text { Odds ratio } \\
p \text {-value }\end{array}$ & $\begin{array}{l}\text { Odds ratio } \\
p \text {-value }\end{array}$ & $\begin{array}{l}\text { Odds ratio } \\
p \text {-value }\end{array}$ \\
\hline DiscAcc & $\begin{array}{l}10.275^{* * *} \\
(0.000)\end{array}$ & $\begin{array}{l}10.696^{* * *} \\
(0.000)\end{array}$ & $\begin{array}{l}10.946^{* * *} \\
(0.000)\end{array}$ & $\begin{array}{l}10.867 * * * \\
(0.000)\end{array}$ & $\begin{array}{l}10.825^{* * *} \\
(0.000)\end{array}$ \\
\hline r_TAXy & & $\begin{array}{l}0.710^{* * *} \\
(0.000)\end{array}$ & & & \\
\hline r_TAXyi & & & $\begin{array}{l}0.716^{* * * *} \\
(0.000)\end{array}$ & & \\
\hline R_TAXi & & & & $\begin{array}{l}0.935 * * * \\
(0.000)\end{array}$ & \\
\hline R_TAXyi & & & & & $\begin{array}{l}0.943 * * * \\
(0.000)\end{array}$ \\
\hline Profit & $\begin{array}{l}2.514 * * * \\
(0.000)\end{array}$ & $\begin{array}{l}2.842 * * * \\
(0.000)\end{array}$ & $\begin{array}{l}2.852 * * * \\
(0.000)\end{array}$ & $\begin{array}{l}2.844 * * * \\
(0.000)\end{array}$ & $\begin{array}{l}2.784 * * * \\
(0.000)\end{array}$ \\
\hline Size & $\begin{array}{l}1.050 * * * \\
(0.000)\end{array}$ & $\begin{array}{l}1.044 * * * \\
(0.001)\end{array}$ & $\begin{array}{l}1.044 * * * \\
(0.001)\end{array}$ & $\begin{array}{l}1.043 * * * \\
(0.001)\end{array}$ & $\begin{array}{l}1.045^{* * *} \\
(0.001)\end{array}$ \\
\hline Issue & $\begin{array}{l}2.530 * * * \\
(0.000)\end{array}$ & $\begin{array}{l}2.319 * * * \\
(0.000)\end{array}$ & $\begin{array}{l}2.327 * * * \\
(0.000)\end{array}$ & $\begin{array}{l}2.342 * * * \\
(0.000)\end{array}$ & $\begin{array}{l}2.373 * * * \\
(0.000)\end{array}$ \\
\hline Litig & $\begin{array}{l}1.224 * * * \\
(0.000)\end{array}$ & $\begin{array}{l}1.205^{* * *} \\
(0.000)\end{array}$ & $\begin{array}{l}1.203 * * * \\
(0.000)\end{array}$ & $\begin{array}{l}1.203 * * * \\
(0.000)\end{array}$ & $\begin{array}{l}1.205^{* * *} \\
(0.000)\end{array}$ \\
\hline CFOVol & $7.148 * * *$ & $6.139 * * *$ & $6.197 * * *$ & $6.368 * * *$ & $6.495 * * *$ \\
\hline
\end{tabular}




\begin{tabular}{llllll}
\hline & $(0.000)$ & $(0.000)$ & $(0.000)$ & $(0.000)$ & $(0.000)$ \\
Range & $1.096^{* *}$ & $1.103^{* *}$ & $1.104^{* *}$ & $1.103^{* *}$ & $1.104^{* *}$ \\
& $(0.031)$ & $(0.021)$ & $(0.020)$ & $(0.022)$ & $(0.021)$ \\
Horizon & $0.934^{* * *}$ & $0.932^{* * *}$ & $0.932^{* * *}$ & $0.932^{* * *}$ & $0.933^{* * *}$ \\
& $(0.000)$ & $(0.000)$ & $(0.000)$ & $(0.000)$ & $(0.000)$ \\
Constant & $0.072^{* * *}$ & $0.082^{* * *}$ & $0.078^{* * *}$ & $0.084^{* * *}$ & $0.082^{* * *}$ \\
& $(0.000)$ & $(0.000)$ & $(0.000)$ & $(0.000)$ & $(0.000)$ \\
Observations & 16,224 & 16,224 & 16,224 & 16,224 & 16,224 \\
Year dummies & YES & YES & YES & YES & YES \\
Industry dummies & YES & YES & YES & YES & YES \\
Likelihood ratio & 1665 & 1689 & 1692 & 1690 & 1685 \\
Area under ROC & 0.687 & 0.688 & 0.689 & 0.688 & 0.688 \\
BIC & $-136,596$ & $-136,611$ & $-136,614$ & $-136,612$ & $-136,607$ \\
chi-square test indep.var. & 229.0 & 252.7 & 255.3 & 253.9 & 248.7 \\
chi-square test indep.var. $p$-value & 0.000 & 0.000 & 0.000 & 0.000 & 0.000 \\
chi-square test year dummies & 811.4 & 810.5 & 809.6 & 778.0 & 805.2 \\
chi-square test year dummies $p$-value & 0.000 & 0.000 & 0.000 & 0.000 & 0.000 \\
chi-square test indstr. dummies & 248.1 & 247.7 & 264.4 & 265.1 & 262.1 \\
chi-square test indstr. dummies_ $p$-value & 0.000 & 0.000 & 0.000 & 0.000 & 0.000 \\
\hline
\end{tabular}

Note. Table 4 provides the logistic regression results of models 1 and 2. The dependent variable Meet equals 1 if the firm meets or beats the management earnings forecast, 0 otherwise. Other variables are as defined in Table 1. A Chi-square test for the joint significance of independent variables, year dummies and industry dummies is performed separately. All continuous variables are winsorized at the 1st and 99th percentiles. ${ }^{* *}, * *$, and $*$ indicate $\mathrm{p}$-value $<0.01, \mathrm{p}<0.05$, and $\mathrm{p}<0.1$, respectively.

Table 5. Logistic regression, meeting management earnings forecasts and BTDs, sensitivity analysis

\begin{tabular}{|c|c|c|c|c|c|c|}
\hline \multirow{2}{*}{$\begin{array}{l}\text { Dependent variable } \\
\text { Independent variables }\end{array}$} & \multicolumn{2}{|c|}{ Meet5 } & \multicolumn{2}{|c|}{ Meet10 } & \multicolumn{2}{|c|}{ Meet15 } \\
\hline & $\begin{array}{c}\text { Odds ratio } \\
p \text {-value }\end{array}$ & $\begin{array}{c}\text { Odds ratio } \\
p \text {-value }\end{array}$ & $\begin{array}{c}\text { Odds ratio } \\
p \text {-value }\end{array}$ & $\begin{array}{c}\text { Odds ratio } \\
p \text {-value }\end{array}$ & $\begin{array}{c}\text { Odds ratio } \\
p \text {-value }\end{array}$ & $\begin{array}{c}\text { Odds ratio } \\
p \text {-value }\end{array}$ \\
\hline DiscAcc & $\begin{array}{c}2.487 \\
(0.248)\end{array}$ & $\begin{array}{c}2.565 \\
(0.233)\end{array}$ & $\begin{array}{c}4.118^{* *} \\
(0.046)\end{array}$ & $\begin{array}{c}4.340 * * \\
(0.039)\end{array}$ & $\begin{array}{c}6.013 * * * \\
(0.007)\end{array}$ & $\begin{array}{c}6.479 * * * \\
(0.005)\end{array}$ \\
\hline $\mathrm{r}_{-}$TAXyi & & $\begin{array}{c}0.895 \\
(0.188)\end{array}$ & & $\begin{array}{c}0.819 * * * \\
(0.008)\end{array}$ & & $\begin{array}{c}0.762 * * * \\
(0.000)\end{array}$ \\
\hline Profit & $\begin{array}{c}1.858 * * * \\
(0.000)\end{array}$ & $\begin{array}{c}1.938 * * * \\
(0.000)\end{array}$ & $\begin{array}{c}1.848 * * * \\
(0.000)\end{array}$ & $\begin{array}{c}1.994 * * * \\
(0.000)\end{array}$ & $\begin{array}{c}1.944 * * * \\
(0.000)\end{array}$ & $\begin{array}{c}2.154 * * * \\
(0.000)\end{array}$ \\
\hline Size & $\begin{array}{c}1.057 * * * \\
(0.001)\end{array}$ & $\begin{array}{c}1.055^{* * *} \\
(0.002)\end{array}$ & $\begin{array}{c}1.109 * * * \\
(0.000)\end{array}$ & $\begin{array}{c}1.106^{* * *} \\
(0.000)\end{array}$ & $\begin{array}{c}1.125^{* * *} \\
(0.000)\end{array}$ & $\begin{array}{c}1.120 * * * \\
(0.000)\end{array}$ \\
\hline Issue & $\begin{array}{c}0.570 * * \\
(0.027)\end{array}$ & $\begin{array}{c}0.555^{* *} \\
(0.021)\end{array}$ & $\begin{array}{c}0.787 \\
(0.300)\end{array}$ & $\begin{array}{c}0.750 \\
(0.216)\end{array}$ & $\begin{array}{c}1.200 \\
(0.422)\end{array}$ & $\begin{array}{c}1.125 \\
(0.606)\end{array}$ \\
\hline Litig & $\begin{array}{c}1.090 \\
(0.189)\end{array}$ & $\begin{array}{c}1.084 \\
(0.217)\end{array}$ & $\begin{array}{c}0.994 \\
(0.926)\end{array}$ & $\begin{array}{c}0.986 \\
(0.810)\end{array}$ & $\begin{array}{c}1.001 \\
(0.992)\end{array}$ & $\begin{array}{c}0.988 \\
(0.834)\end{array}$ \\
\hline CFOVol & $\begin{array}{c}2.463 \\
(0.140)\end{array}$ & $\begin{array}{c}2.352 \\
(0.162)\end{array}$ & $\begin{array}{c}3.734 * * \\
(0.017)\end{array}$ & $\begin{array}{c}3.443 * * \\
(0.026)\end{array}$ & $\begin{array}{c}4.397 * * * \\
(0.005)\end{array}$ & $\begin{array}{c}3.911 * * * \\
(0.010)\end{array}$ \\
\hline Range & $\begin{array}{c}1.078 \\
(0.185)\end{array}$ & $\begin{array}{c}1.082 \\
(0.167)\end{array}$ & $\begin{array}{c}1.085 \\
(0.109)\end{array}$ & $\begin{array}{l}1.091^{*} \\
(0.088)\end{array}$ & $\begin{array}{l}1.091 * \\
(0.073)\end{array}$ & $\begin{array}{l}1.098^{*} \\
(0.053)\end{array}$ \\
\hline Horizon & $\begin{array}{c}0.938 * * * \\
(0.007)\end{array}$ & $\begin{array}{c}0.937 * * * \\
(0.007)\end{array}$ & $\begin{array}{c}0.971 \\
(0.165)\end{array}$ & $\begin{array}{c}0.970 \\
(0.161)\end{array}$ & $\begin{array}{l}0.964 * \\
(0.074)\end{array}$ & $\begin{array}{l}0.964 * \\
(0.071)\end{array}$ \\
\hline Constant & $\begin{array}{c}0.731 \\
(0.646)\end{array}$ & $\begin{array}{c}0.751 \\
(0.676)\end{array}$ & $\begin{array}{c}0.274 * * \\
(0.028)\end{array}$ & $\begin{array}{c}0.287 * * \\
(0.034)\end{array}$ & $\begin{array}{c}0.147 * * * \\
(0.000)\end{array}$ & $\begin{array}{c}0.158 * * * \\
(0.001)\end{array}$ \\
\hline Observations & 10,208 & 10,208 & 12,595 & 12,595 & 13,641 & 13,641 \\
\hline Year dummies & YES & YES & YES & YES & YES & YES \\
\hline Industry dummies & YES & YES & YES & YES & YES & YES \\
\hline Likelihood ratio & 342.0 & 343.7 & 624.6 & 631.5 & 833.5 & 847.8 \\
\hline Area under ROC & 0.613 & 0.613 & 0.637 & 0.638 & 0.651 & 0.653 \\
\hline $\mathrm{BIC}$ & $-81,899$ & $-81,891$ & $-103,819$ & $-103,816$ & $-113,286$ & $-113,291$ \\
\hline chi-square test indep.var. & 117.3 & 119.0 & 172.2 & 178.9 & 193.9 & 207.7 \\
\hline
\end{tabular}




\begin{tabular}{lllllll}
\hline chi-square test indep.var. $p$-value & 0.000 & 0.000 & 0.000 & 0.000 & 0.000 & 0.000 \\
chi-square test year dummies & 118.1 & 117.8 & 238.4 & 237.6 & 336.1 & 0.000 \\
chi-square test year dummies $p$-value & 0.000 & 0.000 & 0.000 & 0.000 & 0.000 & 134.5 \\
chi-square test indstr. dummies & 53.66 & 67.04 & 94.36 & 105.7 & 0.000 & 0.000 \\
chi-square test indstr. dummies $p$-value & 0.000 & 0.000 & 0.000 & 0.000 \\
\hline
\end{tabular}

Note. Table 5 provides the logistic regression results of models 1 and 2. The dependent variable Meet5, Meet10, and Meet15 equal 1 if the firm meets or beats the management earnings forecast by maximum of 5,10 , and 15 cents, respectively, and 0 otherwise. Other variables are as defined in Table 1. A Chi-square test for the joint significance of independent variables, year dummies and industry dummies is performed separately. All continuous variables are winsorized at the 1 st and 99 th percentiles. $* * *, * *$, and $*$ indicate $p$-value $<0.01, p<0.05$, and $p<0.1$, respectively.

\subsubsection{Supplemental Analysis}

\section{Management earnings forecasts and tax avoidance.}

Prior literature analyzes tax avoidance in different settings (see Hanlon \& Heitzman, 2010, for literature review). Hanlon and Heitzman (2010) note that there is no universally accepted definition of tax avoidance. Following Dyreng, Hanlon, and Maydew (2008), I define tax avoidance broadly as (legal and illegal) strategies to minimize taxes, such as tax favored activities, transactions with explicit intent to decrease taxes or engaging in lobbying activities.

Desai and Dharmapala (2006) develop a metric for aggressive tax avoidance practices that is estimated as residuals by regressing BTDs on total accruals. The residuals reflect the component of BTDs that is not attributable to total accruals. This study calculates quarterly discretionary BTDs. Desai and Dharmapala (2006) state that they use ordinary least squares (OLS) regression, while Hoi, Wu, and Zhang (2013) use panel-data model with fixed-effects. I follow Hoi, Wu, and Zhang (2013), and use the within estimator to calculate the discretionary BTDs from the following panel regression with robust standard errors.

$$
B T_{i q}=\beta_{1} \frac{\text { TotAcc }_{i q}}{\text { Assets }_{i, q-1}}+\mu_{i}+\varepsilon_{i q}
$$

where $B T$ is book-tax differences calculated as the difference between income before extraordinary items (Compustat item "IBCQ") and taxable income (as described in section 3.1.) scaled by lagged total assets (Compustat item "ATQ"). $\mu$ is the average value of the residual for firm $i$ over the sample period; and $\varepsilon$ is the deviation of the residual in quarter $q$ from firm $i$ 's average residual.

Desai and Dharmapala (2006) argue that the component of $B T$, which is attributable to total accruals reflects BTDs resulting from earnings management. The remaining part of $B T$, which is not determined by total accruals reflects firms' tax avoidance activity. My argumentation differs from Desai and Dharmapala (2006). In this study, total accruals are decomposed in normal and discretionary accruals and the latter is used as a proxy for earnings management. Therefore, book-tax differences can be decomposed in normal BTDs, the degree of $B T$ resulting from earnings management and from tax avoidance. The component determined by total accruals reflects the normal and the part of BTDs resulting from earnings management. The residual from equation 4 (i.e. regression of $B T$ on total accruals) comprises tax avoidance (TaxAvoid) as suggested by Desai and Dharmapala (2006). TaxAvoid is the combined residual from the panel regression (4a) using fixed effects.

$$
\text { TaxAvoid }_{i q}=\mu_{i}+\varepsilon_{i q}
$$

In general, the degree of BTDs that is attributable to earnings management can be estimated by regressing $B T$ on DiscAcc. These two proxies are highly correlated and would bias the results using model 2 because it requires to include both DiscAcc and a proxy for BTDs (Note 10). Therefore, I estimate the discretionary BTDs, which are beyond the normal part of BTDs. The normal part of BTDs is attributable to normal accruals (NormAcc) that are estimated using equation 1. Regressing $B T$ on NormAcc, the residuals reflect discretionary BTDs that comprise earnings management and tax avoidance activity (DiscBTD).

$$
\begin{aligned}
B T_{i q}= & \beta_{1} \operatorname{NormAcc}_{i q}+\mu_{i}+\varepsilon_{i q} \\
& \text { DiscBTD }_{i q}=\mu_{i}+\varepsilon_{i q}
\end{aligned}
$$

I suppose that greater earnings management and firm's tax avoidance activity result in larger BTDs that are positively associated with the probability of meeting management earnings forecasts. Using TaxAvoid, I analyze whether firms with greater tax avoidance activity are more likely to meet management earnings forecasts (Panel A of Table 6). Using DiscBTD, I investigate whether firms with larger BTDs resulting from earnings 
management and tax avoidance activity are associated with higher probability of meeting management earnings forecasts (Panel B of Table 6). Overall, a positive relationship between the proxies above and Meet would support hypothesis two (H2) that BTDs are incrementally useful in detecting earnings management.

Investigating TaxAvoid [DiscBTD], panel A [panel B] of table 6 shows positive and significant change in odds ratio for DiscAcc using Meet and Meet15 (5.750 and 3.294, respectively) [3.621 and 2.517, respectively]. These findings support the hypothesis two (H2). Using model 2, I find a positive (change in odds ratio: 4.503, 1.323, and 2.043), and significant ( $\mathrm{sig}=0.000$, sig $=0.055$, and $\mathrm{sig}=0.008$ ) relationship between TaxAvoid and Meet, Meet10, and Meet15, respectively. These results imply that firms with a more aggressive tax activity are more likely to meet management earnings forecasts. The change in odds ratio for DiscBTD is positive (change in odds ratio: $4.037,1.037$, and 1.645) and significant ( $\operatorname{sig}=0.000$, sig $=0.106$, and $\operatorname{sig}=0.021$ ) for Meet, Meet 10, and Meet 15, respectively. As expected, higher discretionary book-tax differences increase the probability of meeting management earnings forecasts. This implies that BTDs are incrementally useful in detecting earnings management as suggested in H2. Using both model 1 and model 2 both show that the results tend to be sensitive to the extent of MngError. Restricting the sample to MngError not more than 5 cents, the proxies of interest are not associated with the probability of meeting management earnings forecasts. However, comparing $r_{-} T A X y i$, TaxAvoid, and DiscBT as measures to detect earnings management, the metrics show similar results. The mean comparison test that analyzes differences in predicted probability of meeting the earnings benchmark using $r_{-}$TAXyi, TaxAvoid, and DiscBT, shows no statistical difference between the proxies. This indicates that no one measure appears to be significantly more appropriate to detect earnings management.

Table 6. Logistic regression, meeting management earnings forecasts and tax avoidance

\begin{tabular}{|c|c|c|c|c|c|}
\hline \multicolumn{6}{|l|}{ Panel A } \\
\hline Dependent variable & \multicolumn{2}{|c|}{ Meet } & Meet5 & Meet10 & Meet15 \\
\hline Independent variables & $\begin{array}{c}\text { Odds ratio } \\
p \text {-value }\end{array}$ & $\begin{array}{c}\text { Odds ratio } \\
p \text {-value }\end{array}$ & $\begin{array}{c}\text { Odds ratio } \\
p \text {-value }\end{array}$ & $\begin{array}{c}\text { Odds ratio } \\
p \text {-value }\end{array}$ & $\begin{array}{c}\text { Odds ratio } \\
p \text {-value }\end{array}$ \\
\hline DiscAcc & $\begin{array}{c}10.275^{* * *} \\
(0.000)\end{array}$ & $\begin{array}{c}6.750 * * * \\
(0.002)\end{array}$ & $\begin{array}{c}2.004 \\
(0.386)\end{array}$ & $\begin{array}{c}3.138 \\
(0.114)\end{array}$ & $\begin{array}{c}4.294 * * \\
(0.032)\end{array}$ \\
\hline TaxAvoid & & $\begin{array}{c}5.503 * * * \\
(0.000)\end{array}$ & $\begin{array}{c}2.002 \\
(0.168)\end{array}$ & $\begin{array}{l}2.323^{*} \\
(0.055)\end{array}$ & $\begin{array}{c}3.043 * * * \\
(0.008)\end{array}$ \\
\hline Profit & $\begin{array}{c}2.514 * * * \\
(0.000)\end{array}$ & $\begin{array}{c}2.341 * * * \\
(0.000)\end{array}$ & $\begin{array}{c}1.805^{* * *} \\
(0.000)\end{array}$ & $\begin{array}{c}1.786^{* * *} \\
(0.000)\end{array}$ & $\begin{array}{c}1.858^{* * * *} \\
(0.000)\end{array}$ \\
\hline Size & $\begin{array}{c}1.050 * * * \\
(0.000)\end{array}$ & $\begin{array}{c}1.049 * * * \\
(0.000)\end{array}$ & $\begin{array}{c}1.056 * * * \\
(0.001)\end{array}$ & $\begin{array}{c}1.108 * * * \\
(0.000)\end{array}$ & $\begin{array}{c}1.124 * * * \\
(0.000)\end{array}$ \\
\hline Issue & $\begin{array}{c}2.530 * * * \\
(0.000)\end{array}$ & $\begin{array}{c}2.693 * * * \\
(0.000)\end{array}$ & $\begin{array}{c}0.579 * * \\
(0.032)\end{array}$ & $\begin{array}{c}0.811 \\
(0.366)\end{array}$ & $\begin{array}{c}1.253 \\
(0.324)\end{array}$ \\
\hline Litig & $\begin{array}{c}1.224 * * * \\
(0.000)\end{array}$ & $\begin{array}{c}1.214 * * * \\
(0.000)\end{array}$ & $\begin{array}{c}1.086 \\
(0.207)\end{array}$ & $\begin{array}{c}0.990 \\
(0.868)\end{array}$ & $\begin{array}{c}0.995 \\
(0.936)\end{array}$ \\
\hline CFOVol & $\begin{array}{c}7.148 * * * \\
(0.000)\end{array}$ & $\begin{array}{c}8.715^{* * *} \\
(0.000)\end{array}$ & $\begin{array}{c}2.671 \\
(0.110)\end{array}$ & $\begin{array}{c}4.149 * * \\
(0.010)\end{array}$ & $\begin{array}{c}5.037 * * * \\
(0.002)\end{array}$ \\
\hline Range & $\begin{array}{c}1.096 * * \\
(0.031)\end{array}$ & $\begin{array}{c}1.096 * * \\
(0.031)\end{array}$ & $\begin{array}{c}1.078 \\
(0.185)\end{array}$ & $\begin{array}{c}1.085 \\
(0.110)\end{array}$ & $\begin{array}{l}1.090 * \\
(0.075)\end{array}$ \\
\hline Horizon & $\begin{array}{c}0.934 * * * \\
(0.000)\end{array}$ & $\begin{array}{c}0.934 * * * \\
(0.000)\end{array}$ & $\begin{array}{c}0.938 * * * \\
(0.008)\end{array}$ & $\begin{array}{c}0.971 \\
(0.172)\end{array}$ & $\begin{array}{l}0.965^{*} \\
(0.078)\end{array}$ \\
\hline Constant & $\begin{array}{c}0.072 * * * \\
(0.000)\end{array}$ & $\begin{array}{c}0.077 * * * \\
(0.000)\end{array}$ & $\begin{array}{c}0.752 \\
(0.676)\end{array}$ & $\begin{array}{c}0.283^{* *} \\
(0.032)\end{array}$ & $\begin{array}{c}0.154 * * * \\
(0.001)\end{array}$ \\
\hline Observations & 16,224 & 16,224 & 10,208 & 12,595 & 13,641 \\
\hline Year dummies & YES & YES & YES & YES & YES \\
\hline Industry dummies & YES & YES & YES & YES & YES \\
\hline Likelihood ratio & 1665 & 1683 & 343.9 & 628.3 & 840.6 \\
\hline Area under ROC & 0.687 & 0.688 & 0.614 & 0.638 & 0.652 \\
\hline $\mathrm{BIC}$ & $-136,596$ & $-136,605$ & $-81,892$ & $-103,813$ & $-113,284$ \\
\hline chi-square test indep.var. & 229.0 & 242.5 & 118.9 & 175.1 & 199.3 \\
\hline chi-square test indep.var. $p$-value & 0.000 & 0.000 & 0.000 & 0.000 & 0.000 \\
\hline chi-square test year dummies & 811.4 & 793.7 & 114.1 & 231.7 & 326.9 \\
\hline chi-square test year dummies $p$-value & 0.000 & 0.000 & 0.000 & 0.000 & 0.000 \\
\hline
\end{tabular}




\begin{tabular}{llllll}
\hline chi-square test indstr. dummies & 248.1 & 256.9 & 66.56 & 104.1 & 138.7 \\
chi-square test indstr. dummies_ $p$-value & 0.000 & 0.000 & 0.000 & 0.000 & 0.000 \\
\hline
\end{tabular}

Note. Panel A of Table 6 provides the logistic regression results of models 1 and 2 estimating tax avoidance (TaxAvoid) based of total accruals. The dependent variable Meet equals 1 if the firm meets or beats the management earnings forecast, 0 otherwise. The dependent variable Meet5, Meet10, and Meet 15 equal 1 if the firm meets or beats the management earnings forecast by maximum of 5, 10, and 15 cents, respectively, and 0 otherwise. Other variables are as defined in Table 1. A Chi-square test for the joint significance of independent variables, year dummies and industry dummies is performed separately. All continuous variables are winsorized at the 1 st and 99 th percentiles. ${ }^{* * *}, * *$, and * indicate $p$-value $<0.01, p<0.05$, and $p<0.1$, respectively.

Table 6. Continued, meeting management earnings forecasts and discretionary BTDs

\begin{tabular}{|c|c|c|c|c|c|}
\hline \multicolumn{6}{|l|}{ Panel B } \\
\hline Dependent variable & & & Meet5 & Meet10 & Meet15 \\
\hline Independent variables & $\begin{array}{l}\text { Odds ratio } \\
p \text {-value }\end{array}$ & $\begin{array}{l}\text { Odds ratio } \\
p \text {-value }\end{array}$ & $\begin{array}{l}\text { Odds ratio } \\
p \text {-value }\end{array}$ & $\begin{array}{l}\text { Odds ratio } \\
p \text {-value }\end{array}$ & $\begin{array}{c}\text { Odds ratio } \\
p \text {-value }\end{array}$ \\
\hline DiscAcc & $\begin{array}{c}10.275^{* * *} \\
(0.000)\end{array}$ & $\begin{array}{c}4.621 * * \\
(0.017)\end{array}$ & $\begin{array}{c}1.874 \\
(0.453)\end{array}$ & $\begin{array}{c}2.744 \\
(0.179)\end{array}$ & $\begin{array}{l}3.517 * \\
(0.075)\end{array}$ \\
\hline DiscBTD & & $\begin{array}{c}5.037^{* * *} \\
(0.000)\end{array}$ & $\begin{array}{c}1.661 \\
(0.316)\end{array}$ & $\begin{array}{c}2.037 \\
(0.106)\end{array}$ & $\begin{array}{c}2.645^{* *} \\
(0.021)\end{array}$ \\
\hline Profit & $\begin{array}{c}2.514 * * * \\
(0.000)\end{array}$ & $\begin{array}{c}2.340^{* * *} \\
(0.000)\end{array}$ & $\begin{array}{c}1.817 * * * \\
(0.000)\end{array}$ & $\begin{array}{c}1.792 * * * \\
(0.000)\end{array}$ & $\begin{array}{c}1.864 * * * \\
(0.000)\end{array}$ \\
\hline Size & $\begin{array}{c}1.050^{* * *} \\
(0.000)\end{array}$ & $\begin{array}{c}1.049 * * * \\
(0.000)\end{array}$ & $\begin{array}{c}1.056^{* * *} \\
(0.001)\end{array}$ & $\begin{array}{c}1.109^{* * *} \\
(0.000)\end{array}$ & $\begin{array}{c}1.125^{* * *} \\
(0.000)\end{array}$ \\
\hline Issue & $\begin{array}{c}2.530^{* * *} \\
(0.000)\end{array}$ & $\begin{array}{c}2.707 * * * \\
(0.000)\end{array}$ & $\begin{array}{l}0.577^{* *} \\
(0.031)\end{array}$ & $\begin{array}{c}0.809 \\
(0.363)\end{array}$ & $\begin{array}{l}1.252 \\
(0.325)\end{array}$ \\
\hline Litig & $\begin{array}{c}1.224 * * * \\
(0.000)\end{array}$ & $\begin{array}{c}1.216^{* * *} \\
(0.000)\end{array}$ & $\begin{array}{c}1.088 \\
(0.201)\end{array}$ & $\begin{array}{c}0.991 \\
(0.883)\end{array}$ & $\begin{array}{c}0.997 \\
(0.953)\end{array}$ \\
\hline CFOVol & $\begin{array}{c}7.148^{* * *} \\
(0.000)\end{array}$ & $\begin{array}{c}8.611^{* * *} \\
(0.000)\end{array}$ & $\begin{array}{c}2.609 \\
(0.118)\end{array}$ & $\begin{array}{l}4.078^{* *} \\
(0.011)\end{array}$ & $\begin{array}{c}4.947 * * * \\
(0.003)\end{array}$ \\
\hline Range & $\begin{array}{l}1.096^{* *} \\
(0.031)\end{array}$ & $\begin{array}{l}1.096^{* *} \\
(0.032)\end{array}$ & $\begin{array}{c}1.078 \\
(0.185)\end{array}$ & $\begin{array}{c}1.085 \\
(0.110)\end{array}$ & $\begin{array}{l}1.090^{*} \\
(0.074)\end{array}$ \\
\hline Horizon & $\begin{array}{c}0.934 * * * \\
(0.000)\end{array}$ & $\begin{array}{c}0.934 * * * \\
(0.000)\end{array}$ & $\begin{array}{c}0.938 * * * \\
(0.008)\end{array}$ & $\begin{array}{c}0.971 \\
(0.174)\end{array}$ & $\begin{array}{l}0.965^{*} \\
(0.080)\end{array}$ \\
\hline Constant & $\begin{array}{c}0.072 * * * \\
(0.000)\end{array}$ & $\begin{array}{c}0.077 * * * \\
(0.000)\end{array}$ & $\begin{array}{c}0.745 \\
(0.666)\end{array}$ & $\begin{array}{l}0.281 * * \\
(0.031)\end{array}$ & $\begin{array}{c}0.152^{* * *} \\
(0.001)\end{array}$ \\
\hline Observations & 16,224 & 16,224 & 10,208 & 12,595 & 13,641 \\
\hline Year dummies & YES & YES & YES & YES & YES \\
\hline Industry dummies & YES & YES & YES & YES & YES \\
\hline Likelihood ratio & 1665 & 1681 & 343.0 & 627.3 & 838.9 \\
\hline Area under ROC & 0.687 & 0.688 & 0.613 & 0.638 & 0.652 \\
\hline BIC & $-136,596$ & $-136,602$ & $-81,891$ & $-103,812$ & $-113,282$ \\
\hline chi-square test indep.var. & 229.0 & 240.8 & 118.2 & 174.2 & 198.0 \\
\hline chi-square test indep.var. $p$-value & 0.000 & 0.000 & 0.000 & 0.000 & 0.000 \\
\hline chi-square test year dummies & 811.4 & 795.1 & 115.0 & 232.7 & 328.1 \\
\hline chi-square test year dummies $\_$-value & 0.000 & 0.000 & 0.000 & 0.000 & 0.000 \\
\hline chi-square test indstr. dummies & 248.1 & 257.2 & 66.54 & 104.1 & 138.6 \\
\hline chi-square test indstr. dummies $\_$-value & 0.000 & 0.000 & 0.000 & 0.000 & 0.000 \\
\hline
\end{tabular}

Note. Panel B of Table 6 provides the logistic regression results of models 1 and 2 estimating discretionary BTDs (DiscBTD) based of calculated normal accruals. The dependent variable Meet equals 1 if the firm meets or beats the management earnings forecast, 0 otherwise. The dependent variable Meet5, Meet10, and Meet15 equal 1 if the firm meets or beats the management earnings forecast by maximum of 5, 10, and 15 cents, respectively, and 0 otherwise. Other variables are as defined in Table 1. A Chi-square test for the joint significance of independent variables, year dummies and industry dummies is performed separately. All continuous variables are winsorized at the 1st and 99th percentiles. $* * *, * *$, and * indicate $p$-value $<0.01, p<0.05$, and $p<0.1$, respectively. 
Table 7. Logistic regression, meeting management earnings forecasts and financial crisis

\begin{tabular}{|c|c|c|c|}
\hline Panel A & & & \\
\hline Dependent variable & Meet & Meet & Meet \\
\hline Independent variables & $\begin{array}{c}\text { Odds ratio } \\
p \text {-value }\end{array}$ & $\begin{array}{l}\text { Odds ratio } \\
p \text {-value }\end{array}$ & $\begin{array}{c}\text { Odds ratio } \\
p \text {-value }\end{array}$ \\
\hline DiscAcc & $\begin{array}{c}13.981 * * * \\
(0.000)\end{array}$ & $\begin{array}{c}11.429 * * * \\
(0.000)\end{array}$ & $\begin{array}{c}9.513 * * * \\
(0.002)\end{array}$ \\
\hline Crisis & $\begin{array}{c}6.520 * * * \\
(0.000)\end{array}$ & $\begin{array}{c}7.808 * * * \\
(0.000)\end{array}$ & $\begin{array}{c}7.814 * * * \\
(0.000)\end{array}$ \\
\hline Crisis x DiscAcc & $\begin{array}{c}0.255 \\
(0.348)\end{array}$ & $\begin{array}{c}0.033 * * \\
(0.024)\end{array}$ & $\begin{array}{c}0.011 * * * \\
(0.005)\end{array}$ \\
\hline r_TAXyi & $\begin{array}{c}0.659 * * * \\
(0.000)\end{array}$ & & \\
\hline Crisis x r_TAXyi & $\begin{array}{c}1.598 * * * \\
(0.002)\end{array}$ & & \\
\hline TaxAvoid & & $\begin{array}{c}2.472^{* *} \\
(0.037)\end{array}$ & \\
\hline Crisis x TaxAvoid & & $\begin{array}{c}84.123 * * * \\
(0.000)\end{array}$ & \\
\hline DiscBTD & & & $\begin{array}{l}2.265^{*} \\
(0.060)\end{array}$ \\
\hline Crisis $\mathrm{x}$ DiscBTD & & & $\begin{array}{c}82.279 * * * \\
(0.000)\end{array}$ \\
\hline Controls & YES & YES & YES \\
\hline Observations & 16,224 & 16,224 & 16,224 \\
\hline Likelihood ratio & 1702 & 1704 & 1702 \\
\hline Area under ROC & 0.6888 & 0.6889 & 0.6888 \\
\hline $\mathrm{BIC}$ & $-136,565$ & $-136,567$ & $-136,565$ \\
\hline chi-square test indep.var. & 298.3 & 290.6 & 289.1 \\
\hline chi-square test indep.var. p-value & 0.000 & 0.000 & 0.000 \\
\hline chi-square test year dummies & 472.1 & 462.3 & 462.6 \\
\hline chi-square test year dummies $\_$-value & 0.000 & 0.000 & 0.000 \\
\hline chi-square test indstr. dummies & 263.5 & 256.3 & 256.6 \\
\hline chi-square test indstr. dummies $p$-value & 0.000 & 0.000 & 0.000 \\
\hline odds ratio for Crisis $=1$ & 8.243 & 8.022 & 8.069 \\
\hline odds ratio for Crisis $=1 p$-value & 0.000 & 0.000 & 0.000 \\
\hline
\end{tabular}

Note. Panel A of table 7 provides the logistic regression results of model 3 analyzing the impact of the financial crisis. The dependent variable Meet equals 1 if the firm meets or beats the management earnings forecast, 0 otherwise. Other variables are as defined in Table 1. A Chi-square test for the joint significance of independent variables, year dummies and industry dummies is performed separately. The odds ratio for Crisis $=1$ is calculated for median DiscAcc and median $r_{-}$TAXyi, TaxAvoid, and DiscBTD. All continuous variables are winsorized at the 1 st and 99 th percentiles. $* * *, * *$, and $*$ indicate $p$-value $<0.01, p<0.05$, and $p<0.1$, respectively. 
Table 7. Continued, descriptive statistics for the pre-crisis and crisis-period

\begin{tabular}{|c|c|c|c|c|c|c|c|}
\hline \multicolumn{8}{|c|}{ Panel B } \\
\hline \multirow[b]{2}{*}{ Crisis } & \multicolumn{4}{|l|}{ Meet } & \multicolumn{3}{|l|}{ Meet } \\
\hline & 0 & 1 & Total & Crisis & 0 & 1 & Total \\
\hline 0 & 5,387 & 6,993 & 12,380 & 0 & $44 \%$ & $56 \%$ & $100 \%$ \\
\hline 1 & 886 & 2,958 & 3,844 & 1 & $23 \%$ & $77 \%$ & $100 \%$ \\
\hline Total & 6,273 & 9,951 & 16,224 & & & & \\
\hline
\end{tabular}

\begin{tabular}{|c|c|c|c|c|c|c|c|}
\hline \multicolumn{8}{|c|}{ crisis-period, 2008-2010 } \\
\hline & Mean & Std Dev & Median & Min & Max & $\mathrm{n}$ & \\
\hline TAX & 0.768 & 1.072 & 0.811 & -2.988 & 6.353 & 3,844 & $* * *$ \\
\hline Taxable & 86.8 & 223.4 & 18.0 & 0.0 & $1,764.2$ & 3,844 & $*$ \\
\hline IncomeXTR & 79.4 & 406.6 & 12.3 & $-6,820.0$ & $5,022.0$ & 3,844 & $* * *$ \\
\hline MngError & 0.020 & 0.102 & 0.020 & -1.050 & 0.470 & 3,844 & $* * *$ \\
\hline DiscBTD & 0.003 & 0.047 & 0.010 & -0.787 & 0.227 & 3,844 & $* * *$ \\
\hline TaxAvoid & 0.004 & 0.045 & 0.009 & -0.809 & 0.260 & 3,844 & $* * *$ \\
\hline DiscAcc & 0.000 & 0.030 & 0.000 & -0.234 & 0.191 & 3,844 & \\
\hline r_TAXyi & 0.5 & 0.3 & 0.5 & 0.1 & 1.0 & 3,844 & \\
\hline \multicolumn{8}{|c|}{ pre-crisis period, $1995-2007$} \\
\hline & Mean & Std Dev & Median & Min & $\operatorname{Max}$ & $\mathrm{n}$ & \\
\hline TAX & 0.877 & 0.977 & 0.957 & -2.988 & 6.353 & 12,380 & $* * *$ \\
\hline Taxable & 81.5 & 206.2 & 17.6 & 0.0 & $1,764.2$ & 12,380 & $*$ \\
\hline IncomeXTR & 62.4 & 254.6 & 10.8 & $-4,802.5$ & $4,926.0$ & 12,380 & $* * *$ \\
\hline MngError & -0.048 & 0.167 & 0.005 & -1.100 & 0.470 & 12,380 & $* * *$ \\
\hline DiscBTD & -0.001 & 0.050 & 0.007 & -1.316 & 0.308 & 12,380 & $* * *$ \\
\hline TaxAvoid & -0.001 & 0.049 & 0.005 & -1.281 & 0.310 & 12,380 & $* * *$ \\
\hline DiscAcc & 0.000 & 0.028 & 0.000 & -0.291 & 0.212 & 12,380 & \\
\hline r_TAXyi & 0.5 & 0.3 & 0.5 & 0.1 & 1.0 & 12,380 & \\
\hline
\end{tabular}

Note. Panel B of table 7 provides descriptive statistics for the crisis-period (2008-2010) and the pre-crisis period (1995-2007). The variables are as defined in Table 1. I compare the differences between the two subgroups using a $t$-test on mean. ***,**, and * indicate the the two-tailed $p$-value $<0.01, p<0.05$, and $p<0.1$, respectively.

\section{Management earnings forecasts and financial crisis.}

I perform additional analysis, in which I analyze the influence of the financial crisis on meeting management earnings forecasts. The financial crisis of 2008 caused economic and social costs, uncertainty in capital markets and might have changed managers' disclosure behavior or their activities to meet earnings benchmarks. I suppose that firms are more likely to meet management earnings forecasts in order to increase trust in firm's performance and financial stability. I include an indicator variable (Crisis) to indicate firm-years during the financial crisis. Crisis equals one for the fiscal years 2008-2010, and zero otherwise. I interact Crisis with DiscAcc and the proxies for BTDs to draw conclusions about the effect of the financial crisis on Meet using the following logistic regression.

Model 3:

$$
\begin{aligned}
& \log \left(\frac{\operatorname{Prob}(\text { event })}{\operatorname{Prob}(\text { noevent })}\right)=\text { Meet }_{q}=\alpha_{0}+\alpha_{1} \text { DiscAcc }_{q}+\alpha_{2} \text { Crisis }_{q}+\alpha_{3} \text { Crisis }_{q} \times \text { DiscAcc }_{q}+\alpha_{4} A_{q} \\
& +\alpha_{5} \text { Crisis }_{q} \times A_{q}+\sum \text { Controls }+\varepsilon_{q}
\end{aligned}
$$

where $A$ is $r_{-} T A X y i$, TaxAvoid, or DiscBTD. The control variables (Controls) are the same as described above. Because the indicator variable Crisis is interacted with continuous variables, I must classify a specific value of $r_{-}$TAXyi, TaxAvoid, and DiscBTD to estimate the impact of the financial crisis (i.e. odds ratio) on the probability of meeting management earnings forecasts (Hosmer \& Lemeshow, 2004). I calculate the odds ratio for the median of continuous variables (Note 11). For instance, median $r_{-} T A X y i$ is 0.5 . The effect of the financial crises $($ Crisis $=1)$ is estimated by the exponentiated sum of coefficients for Crisis and the interaction term multiplied by the median $r_{-}$TAXyi $\left[\exp \left(\beta_{\text {Crisis }}+0.5 \times \beta_{\text {Crisis } \times r_{-} \text {TAXyi }}\right)\right]$. 
The results of panel A of table 7 show a positive odds ratio for Crisis (8.243, 8.022, and 8.069) analyzing r_TAXyi, TaxAvoid, or DiscBTD, respectively, all significant at 1\% level. This indicates that firms are more likely to meet management earnings forecasts during the financial crisis. Reasons for this finding may be that managers disclose more pessimistic forecasts or use more extensively earning management to ensure that they meet their earnings targets, and therefore, to avoid negative market reactions. To analyze the differences in the two sub-periods, I report descriptive statistics for the pre-crisis period (1995-2007) and the crisis-period (2008-2010) in panel B of table 7 .

The descriptive statistics show an increase of $36 \%$ of firms that meet the earnings benchmark during the financial crisis $(77 \%)$ in comparison to companies that meet the targets in the pre-crisis period (56\%). Moreover, mean and median MngError is higher during the financial crisis ( 0.020 and 0.020, respectively) in comparison to the pre-crisis period (-0.048 and 0.005 , respectively). Higher positive management earnings forecast errors indicate that managers disclose pessimistic earnings forecasts during the financial crisis. Interesting is that during the financial crisis firms, report higher estimated taxable income (86.8) and higher income before extraordinary items [IncomeXTR] (79.4). However, mean and median DiscAcc are 0.000 in both sub-periods. I find higher mean and median DiscBTD (0.003 and 0.010, respectively) and TaxAvoid (0.004 and 0.009, respectively) for the period 2008-2010. In the pre-crisis period, mean (median) DiscBTD is -0.001 (0.007) and mean (median) TaxAvoid is $-0.001(0.005)$. Overall, these findings indicate more pessimistic earnings forecasts and more earnings management activities during the time of financial crisis. However, investigating Meet5, Meet10, and Meet 15, the results are similar as reported above. Using Meet5, the proxies for earnings management and Crisis are not significant, while using Meet10 and Meet15 show weaker results than presented in table 7. Overall, these findings indicate sensitivity to the extent of management earnings forecast errors.

\section{Conclusions}

This paper combines the literature on earnings management, voluntary disclosures and information content of taxes by investigating the incremental usefulness of book-tax differences in detecting earnings management to meet/beat quarterly management earnings forecasts using different metrics for BTDs. Exploiting greater discretion under GAAP than under tax law, I suggest that managers increase book earnings in ways that do not affect taxable income resulting in higher book-tax differences. I hypothesize that BTDs are incrementally useful to discretionary accruals in detecting earnings management.

This paper extends the literature by decomposing of BTDs (i.e. normal, part of BTDs attributable to earnings management, and tax avoidance) and developing a measure of discretionary BTDs based on approach of Desai and Dharmapala (2006) to analyze their relationship with meeting management earnings forecasts. I also apply the methodology of Lev and Nissim (2004) to calculate the tax-to-book income ratio that comprises total book-tax differences (temporary, permanent, and tax accruals). Moreover, I analyze the impact of the financial crisis of 2008 on the probability of meeting management earnings forecasts.

Using logistic regressions, the results show that higher discretionary accruals increase the probability of meeting management earnings forecasts. I also find that larger book-tax differences are associated with higher probability of meeting earnings benchmarks. Firms with lower ranks of tax-to-book income ratio and higher discretionary BTDs are more likely to meet management earnings forecasts. These findings imply that BTDs are incrementally useful to discretionary accruals in detecting earnings management. Furthermore, aggressive tax avoidance activity is associated with higher probability of meeting management earnings forecasts. Future research should benefit by including these proxies for BTDs when analyzing earnings management. Moreover, the findings indicate that firms are more likely to meet management earnings forecasts during the financial crisis of 2008. It appears that managers disclose more pessimistic earnings forecasts and engage in activities that lead to larger discretionary BTDs and tax avoidance in the crisis-period 2008-2010. However, restricting the sample to the extent of management earnings forecast errors, the results show some sensitivity to forecast errors.

The findings of this study is subject to the following limitations. Although I find robust results, estimating taxable income using financial data can result in measurement error. Managerial incentives (e.g., insider trading) or real earnings management will likely influence the probability of meeting management earnings forecasts. An interesting issue is to analyze the nature of management earnings forecasts (optimistic vs. pessimistic forecasts) and the consequences of the financial crisis in more detail. Future research might consider these issues and shed more light on the information content of taxes by decomposing book-tax differences.

\section{References}

Aboody, D., \& Ron, K. (2000). CEO Stock Option Awards and the Timing of Corporate Voluntary Disclosures. Journal of Accounting and Economics, 29(1), 73-100. http://dx.doi.org/10.1016/S0165-4101(00)00014-8 
Ajinkya, B., \& Michael, J. G. (1984). Corporate Managers' Earnings Forecasts and Symmetrical Adjustments of Market Expectations. Journal of Accounting Research, 22(2), 425-444. http://dx.doi.org/10.2307/2490657

Ajinkya, B., Sanjeev, B., \& Partha, S. (2005). The Association between Outside Directors, Institutional Investors and the Properties of Management Earnings Forecasts. Journal of Accounting Research, 43(3), 343-376. http://dx.doi.org/10.1111/j.1475-679x.2005.00174.x

Altamuro, J., Anne, L. B., \& Joseph, W. (2005). The Effects of Accelerated Revenue Recognition on Earnings Management and Earnings Informativeness: Evidence from SEC Staff Accounting Bulletin No. 101. Accounting Review, 80(2), 373-401. http://dx.doi.org/10.2308/accr.2005.80.2.373

Anilowski, C., Mei, F., \& Douglas, J. S. (2007). Does Earnings Guidance Affect Market Returns? The Nature and Information Content of Aggregate Earnings Guidance. Journal of Accounting and Economics, 44(1-2), 36-63. http://dx.doi.org/10.1016/j.jacceco.2006.09.002

Anonymous. (1997). Earnings Disclosures and Stockholder Lawsuits. Journal of Accounting and Economics, 23(3), 249-282. http://dx.doi.org/10.1016/S0165-4101(97)00010-4

Anonymous. (2003). An Evaluation of Alternative Measures of Corporate Tax Rates. Journal of Accounting and Economics, 35(2), 201-226. http://dx.doi.org/10.1016/S0165-4101(03)00019-3

Anonymous. (2005). The Persistence and Pricing of Earnings, Accruals \& Cash Flows When Firms Have Large Book-Tax Differences. Accounting Review, 80(1), 137-166. http://dx.doi.org/10.2308/accr.2005.80.1.137

Anonymous. (2009). Earnings Management, Corporate Tax Shelters \& Book-Tax Alignment. National Tax Journal, 62(1), 169-186.

Ayers, B. C., Jiang, J., \& Stacie, K. L. (2009). Taxable Income as a Performance Measure: The Effects of Tax Planning and Earnings Quality. Contemporary Accounting Research, 26(1), 15-54. http://dx.doi.org/10.1506/car.26.1.1

Ayers, B. C., Jiang, J., \& Yeung, P. E. (2006). Discretionary Accruals and Earnings Management: An Analysis of Pseudo Earnings Targets. Accounting Review, 81(3), 617-652. http://dx.doi.org/10.2308/accr.2006.81.3.617

Badertscher, B. A., John, D. P., Morton, P., \& Sonja, O. R. (2009). Earnings Management Strategies and the Trade-Off between Tax Benefits and Detection Risk: To Conform or Not to Conform? Accounting Review, 84(1), 63-97. http://dx.doi.org/10.2308/accr.2009.84.1.63

Baginski, S. P., \& John, M. H. (1997). Determinants of Management Forecast Precision. Accounting Review, 72(2), 303-312.

Baginski, S. P., John, M. H., \& Michael, D. K. (2002). The Effect of Legal Environment on Voluntary Disclosure: Evidence from Management Earnings Forecasts Issued in U.S. and Canadian Markets. Accounting Review, 77(1), 25-50. http://dx.doi.org/10.2308/accr.2002.77.1.25

Barton, J., \& Paul, J. S. (2002). The Balance Sheet as an Earnings Management Constraint. Accounting Review, 77(4), 1-27. http://dx.doi.org/10.2308/accr.2002.77.s-1.1

Bartov, E., Dan, G., \& Carla, H. (2002). The Rewards to Meeting or Beating Earnings Expectations. Journal of Accounting and Economics, 33(2), 173-204. http://dx.doi.org/10.1016/S0165-4101(02)00045-9

Blaylock, B., Terry, S., \& Ryan, J. W. (2012). Tax Avoidance, Large Positive Temporary Book-Tax Differences., \& Earnings Persistence. Accounting Review, 87(1), 91-120. http://dx.doi.org/10.2308/accr-10158

Brown, L. D. (1998). Managerial Behavior and the Bias in Analysts'Earnings Forecasts. SSRN Scholarly Paper ID 113508. Rochester. NY: Social Science Research Network. Retrieved from http://papers.ssrn.com/abstract $=113508$

Burgstahler, D., \& Ilia, D. (1997). Earnings Management to Avoid Earnings Decreases and Losses. Journal of Accounting and Economics, 24(1), 99-126. doi:10.1016/S0165-4101(97)00017-7

Burgstahler, D., \& Michael, E. (2006). Management of Earnings and Analysts' Forecasts to Achieve Zero and Small Positive Earnings Surprises. Journal of Business Finance \& Accounting, 33(5/6), 633-652. http://dx.doi.org/10.1111/j.1468-5957.2006.00630.x

Burgstahler, D., Elliott, W. B., \& Michelle, H. (2002). How Firms Avoid Losses: Evidence of Use of the Net Deferred Tax Asset Account. SSRN Scholarly Paper ID 355780. Rochester, NY: Social Science Research Network. Retrieved from http://papers.ssrn.com/abstract $=355780$

Cameron, A. C., \& Pravin, K. T. (2010). Microeconometrics Using Stata. Texas: Stata Press. 
Cazier, R. A., Sonja, O. R., Tian, X., \& Ryan, J. W. (2011). Did FIN 48 Limit the Use of Tax Reserves as a Tool for Earnings Management? SSRN Scholarly Paper ID 1656012. Rochester, NY: Social Science Research Network. Retrieved from http://papers.ssrn.com/abstract $=1656012$

Chuk, E., Dawn, M., \& Gregory, S. M. (2013). Assessing Methods of Identifying Management Forecasts: CIG vs. Researcher Collected. Journal of Accounting and Economics, 55(1), 23-42.

Cohen, D. A., \& Paul, Z. (2010). Accrual-Based and Real Earnings Management Activities around Seasoned Equity Offerings. Journal of Accounting and Economics, 50(1), 2-19. http://dx.doi.org/10.1016/j.jacceco.2010.01.002

Coller, M., \& Teri, L. Y. (1997). Management Forecasts and Information Asymmetry: An Examination of Bid-Ask Spreads. Journal of Accounting Research, 35(2), 181-191. http://dx.doi.org/10.2307/2491359

Comprix, J., Lillian, F. M., \& Andrew, P. S. (2012). Bias in Quarterly Estimates of Annual Effective Tax ates and Earnings Management. Journal of the American Taxation Association, 34(1), 31-53. http://dx.doi.org/10.2308/atax-10152

Cook, K. A., Huston, G. R., \& Thomas, C. O. (2008). Earnings Management through Effective Tax Rates: The Effects of Tax-Planning Investment and the Sarbanes-Oxley Act of 2002. Contemporary Accounting Research, 25(2), 447-471. http://dx.doi.org/10.1506/car.25.2.6

Das, S., Kyonghee, K., \& Sukesh, P. (2011). An Analysis of Managerial Use and Market Consequences of Earnings Management and Expectation Management. Accounting Review, 86(6), 1935-1967. http://dx.doi.org/10.2308/accr-10128

Dechow, P. M., Richard, G. S., \& Amy, P. S. (1995). Detecting Earnings Management. Accounting Review, 70(2), 193-225.

Dechow, P. M., Scott, A. R., \& Irem, T. (2003). Why Are Earnings Kinky? An Examination of the Earnings Management Explanation. Review of Accounting Studies, 8(2-3), 355-384. http://dx.doi.org/10.1023/A:1024481916719

Dechow, P. M., Weili, G., \& Catherine, S. (2010). Understanding Earnings Quality: A Review of the Proxies, Their Determinants and Their Consequences. Journal of Accounting and Economics, 50(2-3), 344-401.

Degeorge, F., Jayendu, P., \& Richard, Z. (1999). Earnings Management to Exceed Thresholds. The Journal of Business, 72(1), 1-33. http://dx.doi.org/10.1086/209601

Desai, M. A. (2003). The Divergence between Book Income and Tax Income.

Desai, M. A., \& Dhammika, D. (2006). Corporate Tax Avoidance and High-Powered Incentives. Journal of Financial Economics, 79(1), 145-179. http://dx.doi.org/10.1016/j.jfineco.2005.02.002

Dhaliwal, D. S., Cristi, A. G., \& Lillian, F. M. (2004). Last-Chance Earnings Management: Using the Tax Expense to Meet Analysts' Forecasts. Contemporary Accounting Research, 21(2), 431-459. http://dx.doi.org/10.1506/TFVV-UYT1-NNYT-1YFH

Diamond, D. W., \& Robert, E. V. (1991). Disclosure, Liquidity., \& the Cost of Capital. Journal of Finance, 46(4), 1325-1359. http://dx.doi.org/10.1111/j.1540-6261.1991.tb04620.x

Dyreng, S. D., Michelle, H., \& Edward, L. M. (2008). Long-Run Corporate Tax Avoidance. Accounting Review, 83(1), 61-82. http://dx.doi.org/10.2308/accr.2008.83.1.61

Fields, T. D., Thomas, Z. L., \& Linda, V. (2001). Empirical Research on Accounting Choice. Journal of Accounting and Economics, 31(1-3), 255-307. http://dx.doi.org/10.1016/S0165-4101(01)00028-3

Francis, J., Donna, P., \& Katherine, S. (1994). Shareholder Litigation and Corporate Disclosures. Journal of Accounting Research, 32(2), 137-164. http://dx.doi.org/10.2307/2491279

Frank, M. M., \& Sonja, O. R. (2006). Do Managers Use the Valuation Allowance Account to Manage Earnings around Certain Earnings Targets? Journal of the American Taxation Association, 28(1), 43-65. http://dx.doi.org/10.2308/jata.2006.28.1.43

Gong, G. L., Li, Y., \& Xie, H. (2009). The Association between Management Earnings Forecast Errors and Accruals. Accounting Review, 84(2), 497-530. http://dx.doi.org/10.2308/accr.2009.84.2.497

Gong, G., Henock, L., \& Amy, X. S. (2008). Earnings Management and Firm Performance Following Open-Market Repurchases. Journal of Finance, 63(2), 947-986. http://dx.doi.org/10.1111/j.1540-6261.2008.01336.x 
Gordon, E. A., \& Peter, R. J. (2004). Unrecognized Deferred Taxes: Evidence from the U.K. Accounting Review, 79(1), 97-124. http://dx.doi.org/10.2308/accr.2004.79.1.97

Graham, J. R., Jana, S. R., \& Douglas, A. S. (2012). Research in Accounting for Income Taxes. Journal of Accounting and Economics, 53(1-2), 412-434. http://dx.doi.org/10.1016/j.jacceco.2011.11.006

Greco, G. (2012). Ownership Structures, Corporate Governance and Earnings Management in the European Oil Industry. SSRN Scholarly Paper ID 2015590. Rochester, NY: Social Science Research Network. Retrieved from http://papers.ssrn.com/abstract=2015590

Green, W. H. (2012). Econometric Analysis (7th ed.). Harlow, England: Pearson Education.

Gupta, S., Rick, L., \& Dan, L. (2011). Do Firms Use Tax Cushion Reversals to Meet Earnings Targets? Evidence from the Pre- and Post-FIN 48 Periods. SSRN Scholarly Paper ID 1163842. Rochester, NY: Social Science Research Network. Retrieved from http://papers.ssrn.com/abstract=1163842

Habib, A., \& Hansen, J. C. (2008). Target Shooting: Review of Earnings Management around Earnings Benchmarks. Journal of Accounting Literature, 27, 25-70.

Hanlon, M. (2003). What Can We Infer about a Firm's Taxable Income from Its Financial Statements? National Tax Journal, 56(4), 831-863.

Hanlon, M., \& Shane, H. (2010). A Review of Tax Research. Journal of Accounting and Economics, 50(2-3), 127-178.

Hassell, J. M., \& Robert, H. J. (1986). Relative Forecast Accuracy and the Timing of Earnings Forecast Announcements. Accounting Review, 61(1), 58.

Healy, P. M., \& James, M. W. (1999). A Review of the Earnings Management Literature and Its Implications for Standard Setting. Accounting Horizons, 13(4), 365-383. http://dx.doi.org/10.2308/acch.1999.13.4.365

Healy, P. M., \& Krishna, G. P. (2001). Information Asymmetry, Corporate Disclosure \& the Capital Markets: A Review of the Empirical Disclosure Literature. Journal of Accounting and Economics, 31(1-3), 405-440.

Hirst, D. E., Lisa, K., \& Shankar, V. (2008). Management Earnings Forecasts: A Review and Framework. Accounting Horizons, 22(3), 315-338. http://dx.doi.org/10.2308/acch.2008.22.3.315

Hoi, C. K., Quiang, W., \& Hao, Z. (2013). Is Corporate Social Responsibility (CSR) Associated with Tax Avoidance? Evidence from Irresponsible CSR Activities. The Accounting Review. http://dx.doi.org/10.2308/accr-50544

Hosmer, D. W., \& Stanley, L. (2004). Applied Logistic Regression (2nd ed.). New York: John Wiley.

Jeter, D. C., \& Lakshmanan, S. (1999). Cross-Sectional Estimation of Abnormal Accruals Using Quarterly and Annual Data: Effectiveness in Detecting Event-Specific Earnings Management. Accounting \& Business Research, 29(4), 299-319. http://dx.doi.org/10.1080/00014788.1999.9729590

Kasznik, R. (1999). On the Association between Voluntary Disclosure and Earnings Management. Journal of Accounting Research, 37(1), 57-81. http://dx.doi.org/10.2307/2491396

Kerstein, J., \& Atul, R. (2007). Intra-Year Shifts in the Earnings Distribution and Their Implications for Earnings Management. Journal of Accounting and Economics, 44(3), 399-419. http://dx.doi.org/10.1016/j.jacceco.2007.04.004

Kim, O., \& Robert, E. V. (1994). Market Liquidity and Volume around Earnings Announcements. Journal of Accounting and Economics, 17(1-2), 41-67. http://dx.doi.org/10.1016/0165-4101(94)90004-3

Kraft, A., Lee, B. S., \& Kerstin, L. (2014). Management Earnings Forecasts, Insider Trading \& Information Asymmetry. Journal of Corporate Finance, 26, 96-123. http://dx.doi.org/10.1016/j.jcorpfin.2014.03.002

Lev, B. (1992). Information Disclosure Strategy. California Management Review, 34(4), 9-32. http://dx.doi.org/10.2307/41166701

Lev, B., \& Doron, N. (2004). Taxable Income, Future Earnings \& Equity Values. Accounting Review, 79(4), 1039-1074. http://dx.doi.org/10.2308/accr.2004.79.4.1039

Manzon, G. B., \& George, A. P. (2002). The Relation between Financial and Tax Reporting Measures of Income. Tax Law Review, 55(2), 175-214.

Matsumoto, D. A. (2002). Management's Incentives to Avoid Negative Earnings Surprises. Accounting Review, 77(3), 483-514. http://dx.doi.org/10.2308/accr.2002.77.3.483 
Mills, L. F., \& Kaye, J. N. (2001). The Influence of Tax and Non-Tax Costs on Book-Tax Reporting Differences: Public and Private Firms. Journal of the American Taxation Association, 23(1), 1-19. http://dx.doi.org/10.2308/jata.2001.23.1.1

Noe, C. (1999). Voluntary Disclosures and Insider Transactions. Journal of Accounting and Economics, 27(3), 305-326. http://dx.doi.org/10.1016/S0165-4101(99)00014-2

Phillips, J., Morton, P., \& Sonja, O. R. (2003). Earnings Management: New Evidence Based On Deferred Tax Expense. Accounting Review, 78(2), 491-521. http://dx.doi.org/10.2308/accr.2003.78.2.491

Plesko, G. A. (1999). Book-Tax Differences and the Measurement of Corporate Income. National Tax Association Proceedings, 171-176.

Rego, S. O. (2003). Tax-Avoidance Activities of U.S. Multinational Corporations. Contemporary Accounting Research, 20(4), 805-833. http://dx.doi.org/10.1506/VANN-B7UB-GMFA-9E6W

Ruland, W., \& Samuel, T. (1990). Factors Associated with the Disclosure of Managers' Forecasts. Accounting Review, 65(3), 710-721.

Schmidt, \& Rew. (2006). The Persistence, Forecasting., \& Valuation Implications of the Tax Change Component of Earnings. Accounting Review, 81(3), 589-616. http://dx.doi.org/10.2308/accr.2006.81.3.589

Schrand, C. M., \& Franco, W. M. H. (2003). Earnings Management Using the Valuation Allowance for Deferred Tax Assets under SFAS No. 109. Contemporary Accounting Research, 20(3), 579-611. http://dx.doi.org/10.1506/480D-098U-607R-5D9W

Seidman, J. K. (2010). Interpreting the Book-Tax Income Gap as Earnings Management or Tax Sheltering. SSRN Scholarly Paper ID 1564253. Rochester, NY: Social Science Research Network. Retrieved from http://papers.ssrn.com/abstract $=1564253$

Skinner, D. J. (1994). Why Firms Voluntarily Disclose Bad News. Journal of Accounting Research, 32(1), 38-60. http://dx.doi.org/10.2307/2491386

Verrecchia, R. E. (2001). Essays on Disclosure. Journal of Accounting and Economics, 32(1-3), 97-180. http://dx.doi.org/10.1016/S0165-4101(01)00025-8

Visvanathan, G. (1998). Deferred Tax Valuation Allowances and Earnings Management. Journal of Financial Statement Analysis, 3(4), 6.

Weber, D. P. (2009). Do Analysts and Investors Fully Appreciate the Implications of Book-Tax Differences for Future Earnings? Contemporary Accounting Research, 26(4), 1175-1206. http://dx.doi.org/10.1506/car.26.4.7

$\mathrm{Xu}$, W. (2010). Do Management Earnings Forecasts Incorporate Information in Accruals? Journal of Accounting and Economics, 49(3), 227-246. http://dx.doi.org/10.1016/j.jacceco.2009.11.005

Zang, A. Y. (2012). Evidence on the Trade-Off between Real Activities Manipulation and Accrual-Based Earnings Management. Accounting Review, 87(2), 675-703. http://dx.doi.org/10.2308/accr-10196

\section{Notes}

Note 1. The verb "meet" indicates meeting and beating the earnings targets.

Note 2. Including binary variables for the fiscal quarters 2-4 reveals comparable results as for the regression with 4 Fqtr.

Note 3. Following Matsumoto (2002), if the value for the fourth quarter is given, missing values of $P P E$ for quarters 1 to 3 are replaced as follows. I calculate the depreciation ratio (quarterly depreciation divided by yearly depreciation) and the year-to year change in $P P E$ in the fourth quarter. In each quarter I add the amount of the year-to-year change in $P P E$ multiplied by the depreciation ratio of the quarter.

Note 4. Using quarterly dummy variables, the analyses show similar results.

Note 5. In 2012, the database has been discontinued.

Note 6. Although I use quantitative EPS forecasts, I cannot rule out the possibility that the results might be biased due to the coverage of CIG.

Note 7. Using at least eight or ten two-digit SIC-quarter observations show comparable results. 
Note 8 . The calculated variance inflation factors (VIFs) support this suggestion. They are somewhat not higher than 1.50 (not reported here).

Note 9. Using quintile ranks of TAX for a given year or decile ranking based on two-digit SIC code show comparable results (available on request) as the findings presented below.

Note 10. Including only the fitted values for BTDs in the logistic regression $\left(B T_{i q}=\beta_{1} \operatorname{DiscAcc}_{i q}+\mu_{i}+\varepsilon_{i q}\right)$, I find a positive and significant association with the probability of meeting management earnings forecasts (available on request). These findings imply that the component of BTDs that is attributable to earnings management increases the likelihood of meeting the earnings targets. However, analyzing the component of normal BTDs, which is attributable to NormAcc $\left(\widehat{B T}=\beta_{1}\right.$ NormAcc $)$ the logistic regression shows a negative change in odds ratio.

Note 11. Using mean $r_{-} T A X y i$, TaxAvoid, or DiscBTD shows com.

\section{Copyrights}

Copyright for this article is retained by the author(s), with first publication rights granted to the journal.

This is an open-access article distributed under the terms and conditions of the Creative Commons Attribution license (http://creativecommons.org/licenses/by/3.0/). 